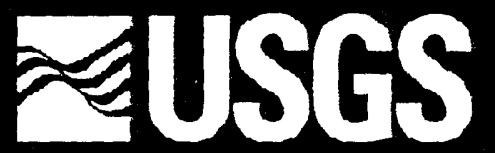

saianca for a changing world

\title{
Sevier-age Thrust Fault Structures Control the Location of Base- and Precious-Metal Mining Districts in the Oquirrh Mountains, Utah
}

by Edwin W. Tooker ${ }^{1}$

Open-File Report 98-234

1998

This report is preliminary and has not been reviewed for conformity with U.S. Geological Survey editorial standards or with the North American Stratigraphic Code. Any use of trade, firm, or product names is for descriptive purposes only and does not imply endorsement by the U.S. Government

U.S. DEPARTMENT OF THE INTERIOR

U.S. GEOLOGICAL SURVEY

${ }^{1}$ Menlo Park, California 
Page

Abstract .......................... 4

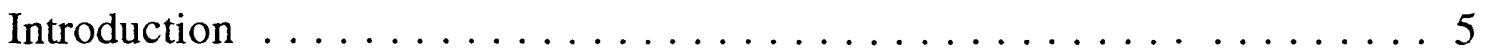

Geologic Setting of North-Central Utah . . . . . . . . . . . . . 7

Oquirrh Mountains Nappes . . . . . . . . . . . . . . . . . . . . ..11

Structural and Stratigraphic Characteristics of Mining Districts in

the Oquirrh Mountains . . . . . . . . . . . . . . ...14

Bingham (West Mountain) mining district . . . . . . . . . .14

Mercur (Camp Floyd) Mining District . . . . . . . . . . . . . 20

Ophir Mining District . . . . . . . . . . . . . . .27

Stockton (Rush Valley) Mining District . . . . . . . . . . 32

Barneys Canyon-Melco Mining Area . . . . . . . . . . . . . 35

Conclusions . . . . . . . . . . . . . . . . . . . . . . . . 39

Acknowledgments . . . . . . . . . . . . . . . . . . .43

References Cited. .44

\section{FIGURES}

Figure Page

1. Location of the Oquirrh Mountains and its mining districts in north-central Utah. . . . . . . . . . . . . 51

2. Foreland of the Sevier thrust belt, the trace of the inferred Uinta trend basement lineament, and the location of

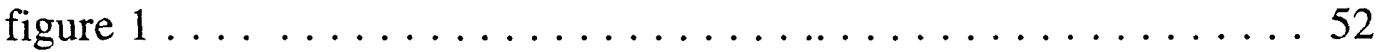

3. Location of nappes in the Oquirrh Mountains and the distribution of igneous rocks. . . . . . . . . . 53

4. Inferred sequence and direction of movement of the nappes that constitute the present Oquirrh Mountains and the inferred location of a basement promontory along the Uinta

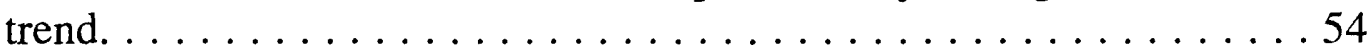

5. Principal structures in the thinned wedge-margin of a nappe emplaced against a basement buttress . . . . . . . . . .55

6 Surface projections of disseminated-porphyry, vein and replacement, skarn, and placer ore bodies in the Bingham

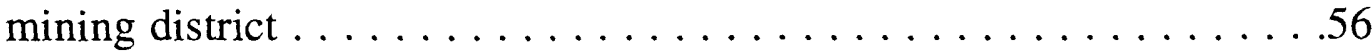

7. Columnar stratigraphic sections of comparable parts of the South Mountain and Bingham nappes in the Stockton 7 1/2minute quadrangle. . . . . . . . . . . . . . . . . . .57

8. Principal fold and fault structures of the Bingham mining district, Utah. . . . . . . . . . . . . . . . . . . 58 
9. Locations of the Mercur, Ophir, and Stockton mining districts in the southern Oquirrh Mountains. . . . . . . . . . . . . . . . 59

10 Fold and fault structures in the Mercur mining district

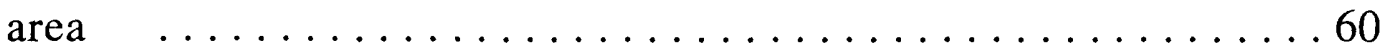

11. Fold and fault structures in the Ophir mining district ......61

12. Fold and fault structures in the Stockton mining district area. .62

13. Fold and fault structures in the Barneys Canyon-Melco mining

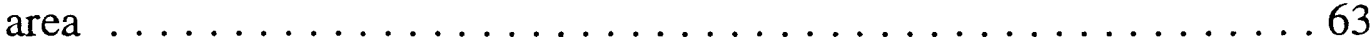

\section{TABLES}

Table

Page

1. Characteristic identifying features of Oquirrh Mountain

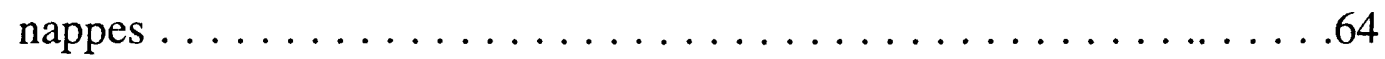

2. Metal production from the Oquirrh Mountains mining districts

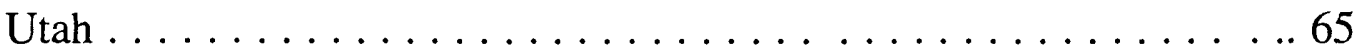

3. Geologic types and ages of intrusive rocks in the mining district areas in the Oquirrh Mountains. . . . . . . . . . . 66 


\title{
Sevier-age Thrust Fault Structures Control of the Location of Base- and Precious-Metal Mining Districts in the Oquirrh Mountains, Utah \\ By Edwin W. Tooker
}

\begin{abstract}
The Oquirrh Mountains lie immediately west of Salt Lake City, Utah, and are part of a geologically complex Paleozoic foreland terrane of the north-northeast-trending Late Cretaceous Sevier thrust belt in central Utah. The range is the site of four historic base- and precious-metal mining districts and a newly recognized disseminated-gold mining area. The mineralized and intruded areas in the Oquirrh Mountains nappes overlie the Uinta trend, an easterly directed, intermittently active, locally uplifted fracture zone, which is inferred to overlie a basement tectonic lineament of regional extent. The mining districts are spatially associated with Tertiary igneous rocks intruded along the extension of the trend in the Oquirrh Mountains. Further, most of the mining districts seem to be located on or near the leading margins of folded, faulted, and thinned upperplate wedges of thrust faults that moved from different parts of the Sevier hinterland. They converged onto a buttress formed by an uplifted part of the Uinta trend underlying the Oquirrh Mountains area.

The porphyry copper, skarn, and vein and replacement deposits at Bingham Canyon, which comprise the largest mining district in the range, are located in the Bingham nappe at the leading edge of the sole Midas thrust fault. The disseminated gold deposits in the Mercur mining district are located near the leading edge of the broken upper plate of the Manning thrust, an imbricate thrust fault within the Bingham nappe. The base- and precious-metal deposits in the Ophir mining district occur in the leading edge of the Manning (imbricate) thrust fault. Base- and precious-metal deposits in the
\end{abstract}


Stockton district are located in the South Mountain nappe at the leading edge of the Stockton thrust, which overrode the Bingham nappe. The Barneys Canyon and Melco disseminated gold deposits, considered to be part of the Bingham mining district by the mine operators, occur in the Pass Canyon nappe.

Stratigraphically similar but structurally distinctive nappes ${ }^{1}$ composed of Paleozoic clastic carbonate, siliceous, and argillaceous sequences of sedimentary rocks, were deformed during their emplacement in the Oquirrh Mountains by differentially directed thrust faults produced by the Late Cretaceous Sevier orogeny. The sedimentary rocks composing the nappes were re-faulted and uplifted locally by later Tertiary Basin-and-Range extensional deformation. Subsequently they were intruded by Tertiary quartz monzonite, granodiorite, latite, and rhyolite stocks, plugs, sills, and dikes and overlain locally by Tertiary latite flows and breccias. There are no known pre-Tertiary igneous rocks exposed.

During the late stages of Tertiary intrusion, metal-rich hydrothermal solutions mixed with meteoric water locally altered and replaced the sedimentary and igneous host rocks. Ore minerals were deposited in the fractured intrusives, in sedimentary rocks along faults initiated by the Sevier-age thrusts, and as replacements of carbonate strata adjoining these faults. The magnitude and tenor of mining districts are believed to be a function of their structural position, the style of deformation within host nappes, their proximity to the Uinta trend, and their spatial association with intrusive rocks.

\section{INTRODUCTION}

The north trending Oquirrh Mountains rise at the south end of Great Salt Lake, about $25 \mathrm{~km}$ west of Salt Lake City, Utah. They include a series of coalescing peaks about $55 \mathrm{~km}$ long and from 10 to

1 Nappe as used here is a sheetlike allochthonous rock unit of sedimentary origin that is moved by thrust faults. 
$25 \mathrm{~km}$ wide that rise from $4,200 \mathrm{ft}$ at the Great Salt Lake to more than $10,500 \mathrm{ft}$ at Lowe Peak in the southern part of the range (fig. 1). The Oquirrh Mountains are a part of the foreland of the Sevier thrust belt (fig. 2), which extends from Alaska to Mexico (Hayes, 1976). The structural and stratigraphic characteristics of nappes composing the thrust belt in central Utah were delineated by Roberts and others (1965), Morris (1983), and Tooker (1983). The Oquirrh Mountains nappes are presumed to overlie a cratonal basement terrane that contains the Uinta-Cortez axis or Uinta trend (fig. 2), an east-trending mobile structural zone that facilitated intrusion of igneous rocks and their associated hydrothermal ore-bearing solutions from depth (Erickson, 1976).

\section{FIGURES 1 and 2, NEAR HERE.}

The co-location of ore deposits on the upper plates of thrust faults, while known, has seldom been observed on a mountain-range scale. James (1982) identified a number of ore deposits containing substantial amounts of high-grade base- and precious-metal ores localized along thrust faults in the Wasatch Mountains. These are generally small ore bodies within individual mines. Regional geologic mapping in the Oquirrh Mountains disclosed the direct association of regional thrust-fault-related structures with several large mining districts (Tooker, 1999).

Descriptions of the geologic terranes developed in the range during the Late Cretaceous Sevier Orogeny are based on observations by Tooker (1983, 1999), and Tooker and Roberts, (1998).

Characteristics of Tertiary-age ore deposits contained in the Oquirrh Mountains are best described by others. Those at Bingham and Barneys Canyon-Melco were from reports by Peters and others (1966), Rubright and Hart (1968), Atkinson and Einaudi (1978), Babcock and others (1995), and Presnell and Parry (1996). The deposits at Mercur were reported by Kornze and others (1985). Deposits in the Ophir and Stockton districts were described by Gilluly (1932). 
Many authors of the individual geologic reports cited herein may not concur in whole or in part with my regionally-focused interpretation of the origin of the Oquirrh Mountains ore deposits. For example, a recent alternative interpretation of the origin of the structures and ore deposits in the Oquirrh Mountains was based on geochemical and geochronologic data by Wilson and Parry (1995) at Mercur, and the geologic-geochemical-geochronologic data of Presnell and Parry (1996) at the Barneys Canyon and Melco deposits. These data lead to their conclusions that are at variance with the author's, and are discussed later in the report. Final resolution of the problem of origin undoubtedly will require additional information.

\section{GEOLOGIC SETTING OF NORTH-CENTRAL UTAH}

Observed and inferred geologic features indicative of a sequential evolution of north-central Utah and the Oquirrh Mountains summarized here are more fully documented by Tooker (1999). These include (1) recognition of a Uinta-trend lineament and its impact on the accumulation of Paleozoic sedimentary rocks in two adjoining miogeoclinal basins on a west-facing Precambrian craton shelf, (2) compression of the region by Late Cretaceous Sevier thrust faults producing the nappes, (3) Basin and Range extensional faulting and uplift, (4) introduction of Tertiary intrusive and extrusive rocks, and accompanying hydrothermal deposition of the ore-forming materials, and (5) unroofing by Quaternary uplift, glaciation, and erosion.

A Precambrian craton terrane underlying north-central Utah is exposed in the Wasatch Mountains, but mostly is concealed to the west. These cratonal rocks formed a north-trending, west-dipping shelf of the North American continent during the Paleozoic.

Basement rocks lying north of a generally west-striking fault zone along the north flank of the Uinta Mountains, compose the Archean Wyoming shield (King, 1976; Bryant, 1979, and 1988). Those south of the fault zone are composed predominantly of Proterozoic rocks 
(Sears and others, 1982). This fault zone is believed to have deep seated structural significance both westward and to the east, and is coincident here with what is known as the Uinta trend. The generalized trace of the trend (fig. 2), and its westward projection were described by Webb, (1958), Roberts, and others (1965), and Erickson (1976). The trend is defined permissively by (1) an alignment of Cenozoic intrusive and extrusive rocks (Stewart and others, 1977; Moore and McKee, 1983; and John, 1989), (2) evidence of periodic uplift along parts of the trend in western Utah and eastern Nevada (Brooks, 1956; Webb, 1958; Roberts and Tooker, 1969; and Coats, 1987), and (3) geophysical data (Stewart, 1978; Mabey and others, 1978; Eaton and others, 1978; and Bankey and Campbell, 1989). Sims and others (1987) described a possible eastward extension of the Uinta trend or a comparable mineralized lineament in the midcontinent, which they attributed to the accretion of a Proterozoic terrane onto an Archean shield.

Paleozoic sedimentary rocks were deposited on an irregular, broad, shallow, gradually subsiding craton shelf (Gordon and Duncan, 1970; Stewart and Poole, 1974; and Peterson, 1977). The shelf was elongated generally north-south, and located an undetermined distance west of the autochthonous, nearer-shore, more slowlysubsiding part of the craton shelf presently exposed in the Wasatch Mountains (Baker and others, 1949; Crittenden and others, 1952; and Rose, 1967). Local intermittent uplifts along the Uinta trend in western Utah and eastern Nevada during the Paleozoic separated the deposition of shelf sediments into an Oquirrh basin on the south and the Sublette basin on the north (Peterson, 1977). Paleozoic sedimentary rocks exposed in the Oquirrh Mountains were deposited in different parts of these Sevier hinterland basins.

Studies in the hinterland area of northeastern Nevada and northwestern Utah by Camilleri and others (1994), Miller and Hoisch (1995), and Elison (1995), described relatively local igneous and metamorphic evidence for a Late Jurassic Elko orogeny. Jurassic orogenic activity was proposed as the source of illite clay mineral 
dates in wall rocks adjoining the Mercur and Barneys Canyon-Melco disseminated gold deposits by Wilson and Parry (1995) and Presnell and Parry (1996). The author's conclusion of the limited significance of this orogeny with respect to the ore deposits in the Oquirrh Mountains is considered later in this report.

Five nappes composed of sedimentary rocks from these basins were thrust eastward in sequence and merged in the Oquirrh Mountains foreland (figs. 3 and 4) during the compressional phase of the Late Cretaceous Sevier orogeny (Price, 1989; Armstrong, 1968; Roberts and Crittenden, 1973; Tooker 1983; and Hamilton, 1988). Possible mechanisms for producing Sevier-age decollement thrust faults, whether by gravity slide proposed by Rubey and Hubbard (1959) or regional detachment driven by a heated magmatic arc in the hinterland and cooler foreland areas described by Allmendinger and Jordan (1981), are considered by Armstrong (1972), Roberts and Crittenden (1973), Hayes, 1976, Allmendinger and Jordan (1981), Allmendinger, and others (1983), and Hamilton (1988). The manner of thrust movement and the distance moved can not be determined in the Oquirrh Mountains. However, Crittenden (1961) estimated that some of the Utah nappes may have been transported eastward as much as $64 \mathrm{~km}$.

\section{FIGURES 3 and 4, NEAR HERE.}

Sole and imbricate thrust faults and tear and conjugate normal faults observed on a thinned forward nappe margin were formed during its emplacement and folding. The sole thrust may have moved eastward an unknown but probably substantial distance. Through-going, symmetrical, broad, open, high-amplitude main folds were produced in the nappe. Generally wide-spaced conjugate normal, steep-dipping faults, which generally have only small displacement of stratigraphic units, also were formed (Tooker, 1999). At the same time, movement on imbricate thrusts within the nappe were of much less magnitude. Close-spaced secondary lowamplitude and discontinuous thrust-formed folds developed are 
commonly cut off and offset modestly by steep-dipping short-length tear faults.

The structures observed in Oquirrh mining districts represent local variations in more highly-stressed parts of a main fold (fig. 5) at the thinned leading edge of the thrust. Local forward horizontal or vertical stretching, arching, and overturning of a main fold as the nappe rose and lapped obliquely over the Uinta trend buttress, resulted in formation of abundant local branching, close-spaced, nearly vertical tension faults normal to the fold axes. Tight, smallamplitude secondary folds formed along the frontal edges of thrust plates were separated by tear faults, and the broken upper part of the fold offset forward as a local imbricate thrust. Conjugate normal faults are also produced during the folding and subsequent uplift of that part of the nappe overlying the Uinta trend. Later, during Basin-and-Range extension, some of these tear and conjugate faults were displaced further as normal faults. The sequence of types of faults generated in the host sedimentary rocks overlying the Uinta trend is not always clear. Suffice to say, they provided the potential openings used subsequently in the introduction of magma and hydrothermal solutions (Field and Moore, 1971; Tooker and Roberts, 1988, p. 7-8).

\section{FIGURE 5, NEAR HERE.}

During the Late Cenozoic, following the period of plate convergence and crustal compression of the Sevier orogeny, crustal extension produced Basin and Range block faulting, forming the easttilted Oquirrh Mountains (Stewart, 1978; Eaton, 1979; and Speed and others, 1988). Intrusion of subvolcanic quartz monzonitic porphyry stocks, sills, and dikes in faulted Oquirrh rock terranes in the Bingham (Lanier, and others, 1978), Ophir (Gilluly, 1932), and Stockton (Moore, 1973c) mining districts during the Eocene and Oligocene was followed by the extrusion of andesitic to latitic volcanic and volcaniclastic rocks mainly along the east side of the range (Smith, 1961; Moore, 1973a, and Swensen, 1975). Late-stage 
hydrothermal solutions mixed with meteoric water containing baseand precious-metals were precipitated locally near the end of intrusive activity at Bingham (Moore, 1973c) in faults, in fractured and altered intrusions, and in structurally- and mineralogicallyprepared, stratigraphically-favorable sedimentary rocks adjoining the intrusions. Smaller and more sparsely distributed intrusive rhyolite, rhyolite porphyry, and granodiorite and monzonite porphyry stocks, dikes, or sills of similar Eocene and Oligocene ages (Gilluly, 1932; Moore and McKee, 1983) were emplaced locally into sedimentary rocks in the Mercur, Ophir, Stockton, and Barneys Canyon-Melco areas (fig. 3). Most of these intrusions also are spatially associated with ore deposits.

Finally, uplift, which raised the Uinta trend area, and Pleistocene glaciation both caused accellerated erosion, unroofed the mineralized areas in the Oquirrh Mountains and produced extensive alluvial fans and pediments along the range fronts. During the glacial interval, a very extensive freshwater lake formed in the valleys between ranges (Crittenden, 1963). The Lake Bonneville shorelines were sites for the formation of widespread, locally well-preserved bars, spits, and other coarse clastic shoreline deposits and erosional features. The most extensive examples of these surficial deposits are concentrated along the range front overlying the Uinta-trend zone; this distribution reinforces the observation that active, postmineralization uplift and erosion occurred along the Uinta trend.

\section{OQUIRRH MOUNTAINS NAPPES}

Five structurally and stratigraphically distinctive nappes located in the Oquirrh Mountains (fig. 3), include the Rogers Canyon, Pass Canyon, Bingham, South Mountain, and Fivemile Pass nappes. Base- and/or precious-metal ore deposits occur in some of the nappes (Tooker and Roberts, 1988, and 1998). The Rogers Canyon nappe lies at the north end of the range, in large part north of Nelson Peak; no mineral deposits are recognized in it. The Pass Canyon nappe, exposed across the central part of the range north and west of 
the Bingham mine and south of Nelson Peak, contains the Barneys Canyon-Melco deposits. The Bingham nappe in the southern twothirds of the range, mostly south of the Bingham mine, is the site of the Bingham, Mercur, and Ophir mining districts. The South Mountain nappe is located mainly on South Mountain, west of the central part of the Oquirrh Mountains, but also includes the Stockton mining district area in the Oquirrh Mountains, immediately east of the town. The Fivemile Pass nappe is located north of Fivemile Pass at the very south end of the range and contains no base- or precious-metal deposits.

The identification and sequence of emplacement of the five Oquirrh Mountains nappes were based on permissive interpretation of stratigraphic, structural, and geophysical observations (Tooker, 1983, and 1999). Although the ages and compositions of stratigraphic units in the nappes overlap or are similar, there are sufficient distinguishing features that, in combination with their structural attributes, permit recognition of them as individuals. Stratigraphic characteristics of the nappes and the relative directions and timing of thrust fault movements in the Oquirrh Mountains are summarized in table 1 .

Table 1, NEAR HERE.

Subtle yet persistent differences in the stratigraphic composition of individual nappes, which varied from north to south along the craton shelf, are believed to be the result of sedimentation from different sources that bounded the Paleozoic sedimentary basins. These differences are most marked in Late Mississippian and Early Permian sedimentary rocks (Tooker and Roberts, 1988).

The Sevier decollement was broken into parts that moved eastward as individual nappes. The geometry of fold and fault structures in the Oquirrh Mountains nappes indicate that they travelled along separate paths into the foreland. The great diversity of these structures contrasts with more-regular less-disrupted nappe 
structures to the north in the Wyoming salient (Oriel and Armstrong, 1966) and to the south in the vicinity of Eureka, Utah (Morris, 1983). These nappes moved into topographic lows in the foreland whereas the Oquirrh Mountains nappes moved toward and onto a ridge or buttress in the craton platform overlying the Uinta trend. Here the nappes were diversely deflected (fig. 4), much as the lobes of a glacier are deflected when approaching an obstacle (Tooker, 1970). The different styles and magnitudes of the nappe fold structures observed in the 7-1/2-minute geologic quadrangle maps indicated the relative directions of plate movement (Tooker and Roberts, 1971, 1988, 1992; Tooker, 1987, 1992). This assumes that the final direction of nappe movement was normal to the general trend of fold axes, and represents the approximate direction of tectonic transport.

The northern outcrops of the Pass Canyon nappe are intensively deformed and altered. It is presumed to have been the first east-directed lobe of the Sevier thrust belt to arrive in the Oquirrh Mountains (fig. 4). Its true thickness is undetermined here. The Permian sedimentary rocks of the nappe seem to be a muchdisturbed, thinner border facies resembling similar-age rocks in the Nebo-Charleston nappe in the Wasatch Mountains (Baker and others, 1949, Tooker, 1983). On the basis of stratigraphic composition and structural complexity, the Pass Canyon nappe may be a split off from the Nebo-Charleston nappe. It is believed to be a part of that nappe intercepted on the north side of an unexposed tear fault and stranded on the Uinta-trend buttress.

The nearly 8,000 m-thick Bingham nappe, composed of lower and upper Paleozoic sedimentary rocks, arrived next and overlapped the Pass Canyon nappe from the west, forming a bold pattern of main and secondary folds and imbricate thrust faults. The Rogers Canyon nappe, composed of a nearly 4,000 m-thick section of Upper Paleozoic sedimentary rocks overrode both the Pass Canyon and Bingham nappes from the northwest. The arrival times are less certain for the 2,363 m-thick South Mountain and unmeasured but thinner Fivemile Pass nappes composed of Upper Paleozoic rocks, 
which moved from the south-southwest. They apparently postdate the arrival of the Bingham nappe, which they overlap.

\section{STRUCTURAL, STRATIGRAPHIC, AND ORE DEPOSIT CHARACTERISTICS OF MINING DISTRICTS IN THE OQUIRRH MOUNTAINS}

This brief regional geologic perspective for the development of Oquirrh Mountains nappes provides a setting for more detailed examination of the stratigraphic, structural, and intrusive features of mining districts in individual nappes. Descriptions of these features in the mining districts are the author's responsibility. Geologic data for individual ore deposits are derived from cited reports.

\section{Bingham (West Mountain) Mining District}

The Bingham (originally known as the West Mountain) mining district includes the largest deposits in the central part of the Oquirrh Mountains, and is located about $32 \mathrm{~km}$ southwest of Salt Lake City, Utah. The district is centered on the very large quartz monzonitic Bingham porphyry open-pit copper mine, underground copper skarn deposits, and peripheral base- and precious-metal vein and replacement deposits. The district is located geologically in a complexly folded, faulted, and thinned wedge-shaped leading edge of the Bingham nappe composed of Upper Paleozoic carbonate-quartzrich sedimentary rocks. The deposits are spatially associated with Tertiary intrusive and extrusive rocks (Bray and others, 1975, Tooker and Roberts, 1988; Tooker, 1990).

Early accounts of the discovery and development of lead-zinc and silver lodes and porphyry copper and gold deposits were described by Boutwell (1905). Recent mining activities in the district (fig, 6) are detailed by James (1978), Peters and others (1966), Atkinson and Einaudi (1978), Cameron and Garmoe (1983), and Babcock and others (1995). Production data from the Bingham mining district (Babcock, and others, 1995, and U.S.B.M. 1924-1993) 
compiled in table 2 underscores the great magnitude of the open-pit and underground mine production of copper, molybdenum, and gold, and lesser amounts of silver, lead, and zinc from this world-class deposit. A number of minor metals are also produced.

FIGURE 6 and TABLE 2, NEAR HERE

Stratigraphy.--The stratigraphic sequence of structurally competent sedimentary rocks at Bingham includes two Upper Pennsylvanian-age formational units of the Oquirrh Group (Tooker and Roberts, 1970), shown in part in the columnar section, figure 7. The Butterfield Peaks Formation at the base consists of cyclically interbedded calcareous quartzite, orthoquartzite, calcareous sandstone, and fossiliferous, arenaceous, cherty, argillaceous, and fine-grained dense limestones. The Clipper Ridge Member of the Bingham Mine Formation is composed predominantly of cyclically interbedded orthoquartzite, calcareous quartzite, and quartzose sandstones interbedded with several thick- to intermediate-thick limestones. The Jordan and Commercial limestone beds at the base of the member are the principal hosts of vein and replacement basemetal deposits. The Markham Peak Member (not shown in figure 7) contains interbedded orthoquartzite, calcareous quartzite, calcareous sandstone, and a few thin fusulinid-bearing arenaceous limestone units, which also are replaced locally near the intrusives.

\section{FIGURE 7, NEAR HERE.}

Structures.--Fold and fault surface structures in the Bingham mining district, shown in figure 8 , are located on the forward margin of the thinned upper plate of the Midas thrust at the northern end of the Bingham nappe. The forward part of the Bingham nappe was thinned by shearing as the sole thrust rose against the Uinta trend buttress and cut across the stratigraphic section. Between Ophir and Bingham, in a distance of about $17 \mathrm{~km}$, more than $4,000 \mathrm{~m}$ of the lower Paleozoic section as well as some of the lower parts of the Pennsylvanian Butterfield Peaks Formation were sheared out of the 
upper plate of the nappe. The Midas thrust and complex folding at the base of the nappe are concealed at the surface by northweststriking, south-side-down, near-vertical cross faults that bring rocks of the Pass Canyon nappe into contact with those of the Bingham nappe. The location of the Midas thrust is inferred below tight to overturned folds observed in the North ore body (Tracy Shrier, 1988, oral commun.; Tooker, 1990, fig. E4; and Babcock and others, 1995, fig. 7). The "Midas thrust" mapped north of the open pit mine workings by James and others (1961), which they correctly considered to be of local extent, is one of the small thrust-fault imbrications above the sole thrust. This imbricate fault is comparable with those mapped on Markham Peak (Atkinson and Einaudi, 1978; Tooker and Roberts, 1988).

\section{FIGURE 8, NEAR HERE}

The Bingham syncline, the most prominent (main) fold in the district, is a tight, and locally overturned fold at the crest of the range on Markham Peak. The axial plane of the fold dips southwest and strikes southeastward toward the Bingham Canyon fault. Location of the syncline is obscured between the Bingham Canyon fault and a branch of the Main Hill fault, where (secondary) folds in the beds are very tightly folded and overturned. Southeastward across the northeast-trending Bingham Canyon fault, the Bingham syncline is offset as much as $0.2 \mathrm{~km}$ to the northeast and bends southeastward as a broad open fold with a near-vertical axial plane. In contrast, axial planes of folds in the Pass Canyon nappe strike northerly. The northeast-striking, steeply-dipping faults that offset the Bingham syncline are obscured by extensive mine dumps. Observation of the continuity of subparallel-trending dike intrusions that occur discontinuously along the faults is also limited by that cover.

The marked difference in style of folding across the northeast Bingham Canyon fault zone suggests that movement on its northwest side was impeded more than on its southeast side. This caused 
tightening and overturning of the Bingham syncline and the production of imbricate thrusts such as those on Markham Peak. On the southeast side of the Bingham Canyon fault, the broad open-fold shape of the Bingham syncline indicates that nappe movement was less restricted. Even there, fault imbrications above the basal Midas thrust, such as the "Midas thrust" of James and others (1961) resulted.

Limited offset of bedding across clustered, steeply-dipping, northeast-trending, branching faults accompanied by local overturning of folds in the nappe imply the development of tension in the folds during early stages of emplacement. Bending of the fold from a tight, locally overturned west-northwest trend into a broad southeast-trend occurred as the Bingham nappe advanced tangentially onto the Uinta-trend buttress (Tooker and Roberts, 1998). Somewhat farther along in the sequence of nappe emplacement onto the buttress, some of these faults locally developed into tear-faults, modestly offsetting secondary folds. During subsequent formation of the Basin and Range structures, many of the same vertical dipping faults seem to have been reactivated as normal faults. Open parts of the main northeaststriking faults ultimately became channelways for the movement and emplacement of Tertiary magma.

Intrusives.--The Bingham and Last Chance stocks are located mainly on the southeastern side of the northeast-trending dike swarm emplaced along the faults in Bingham Canyon (fig 8). The more tightly-folded northwest side was not as open a structural site for monzonitic magma intrusions or for hydrothermal sulfide solution channelways. The Bingham stock is located mainly northeast of the Giant Chief fault (Lanier, 1978) in open parts of nappe folds that parallel the Bingham syncline. The Bingham and Last Chance stocks are separated by a block of locally overturned, tightly-folded, eaststriking sedimentary rocks (Galena Gulch folded zone) that also are cut by imbricate thrust faults and dike or sill intrusions. The folds in this block are truncated on the west by the Main Hill fault and on the 
east by the Giant Chief fault. They lie at nearly right angles to the Bingham syncline and its adjoining folds. The Last Chance stock occurs south of the Galena Gulch block in an open-folded nappe terrane.

Sequential introduction of magma along northeast-trending faults probably was accompanied by continuing uplift and reopening of feeder faults overlying the Uinta trend. The compositional and age relations of intrusions listed in table 3 in the Bingham nappe aweremore fully detailed by Moore (1973b) and Warnaars and others (1978).

\section{TABLE 3, NEAR HERE}

The Bingham nappe folds and abundant intrusions do not project into the Pass Canyon nappe north of the A.J. and Midas faults, even though the steep northeast-striking faults extend across the plate contact. A few monzonite porphyry dikes similar in composition and age to the Bingham intrusive rocks crop out discontinuously in the Pass Canyon nappe (Babcock and others, 1995, and Tooker and Roberts, 1988).

Ore deposition--The mineral-zoned Bingham mining district includes intrusive-centered and adjoining vein and replacement ore bodies. The central copper-molybdenum-gold ores in the altered Bingham stock and its associated dikes are mainly present along closely-spaced fractures in altered porphyritic quartz monzonite intrusion (Peters and others, 1966; and John, 1978). Less significant mineralization is located mainly along vein-faults in the adjoining less-fractured, mostly-unaltered Last Chance stock. The two stocks connect at depth (Babcock and others, 1995).

Highly saline hydrothermal fluids $\left(400^{\circ}\right.$ to $\left.600^{\circ} \mathrm{C}\right)$ that altered the host rocks and deposited metals are inferred from the chemical and isotopic compositions of fluid inclusions in the rocks (Field and Moore, 1971; Moore and Nash, 1974; and Bowman and others, 1987). 
The temperature decreased to $300^{\circ} \mathrm{C}$ in the peripheral deposits (Roedder, 1971). Fluid inclusions and breccia pipes are evidence of shattering and boiling within the Bingham stock (Moore and Nash, 1974). Nearly vertical unmineralized breccia pipes as much as 180 $\mathrm{m}$ diameter occur along the south and east sides of the Bingham stock (Rubright and Hart, 1968).

Extensive vein and replacement base-and-precious metal deposits in the outer zone sedimentary rocks (Rubright and Hart, 1968) surround the porphyry deposits (fig. 6). These outer zone ores occur along faults that provided access for hydrothermal solution movement into several of favorably reactive carbonate rocks in the Butterfield Peaks and Bingham Mine Formations (Tooker and Roberts, 1970). The base of the Clipper Ridge Member of the Bingham Mine Formation contains two thick beds, the Jordan and Commercial Limestones, which have been extensively replaced in the U.S., Lark, Utah Metals and Apex-Highland Boy mines. Several thinner carbonate beds in the predominantly calcareous quartzite and orthoquartzite, which compose the overlying Clipper Ridge and Markham Peak Members, also are mineralized where they cross northeast-trending fault systems in the district (Hunt, 1924; Rubright and Hart, 1968). Rubright and Hart also described the occurrence of fissure base-metal ores in the low-temperature outer zone southwest of the main Bingham porphyry deposits that contain siliceous gold-silver ores and rare native gold. The amount of gold in these veins generally increased toward the outer fringes and decreased with depth.

Close to the intrusion in lower parts of the mine, the Clipper Ridge carbonate rocks were metasomatized (Atkinson and Einaudi, (1978). Skarn alteration of the thick Commercial Limestone was divided into six mineralogic zones (from unaltered to contact with the intrusion) by Reid (1978): (1) marble, (2) wollastonite, (3) cristobalite, (4) garnet-clay, (5) garnet-quartz,, and (6), amphiboliteepidote. Atkinson and Einaudi (1978) described the association of sulfide ores within these skarn facies. An early copper-gold 
deposition was followed by local high-grade gold mineralization (Cameron and Garmoe, 1983).

A number of much smaller vein and replacement deposits occur southwest of the Bingham mining district in Middle, Butterfield, and West Canyons. These deposits also are located on the bowed folded and faulted upper plates of the Middle-Butterfield and West Canyon imbricate thrusts, Commonly they are associated with dikes that seem to be compositionally similar but less abundant than those in the Bingham mining district. (Tooker, 1999, and Tooker and Roberts, 1998).

Conclusions.-The large zoned porphyry, skarn, and vein and replacement ore assemblages in the Bingham district are spatially associated with the largest and hottest intrusions and extrusions in the Oquirrh Mountains. The deposits was sited in structures prepared in locally-stressed parts of the Bingham nappe by the Sevier-age Midas thrust fault. The nappe was deformed as it ramped up onto the foreland buttress of the Uinta trend. Deformation produced folds and fractures in carbonate-rich, Upper Paleozoic host rocks in the frontal wedge-shaped, tightly folded and faulted edge of the nappe. The Uinta trend overlies a basement lineament that tapped sources of magmatic materials. The zone of local uplift structures along the trend provided fault access for magmatic materials into the overriding nappe. The intrusions pushed upward as stock, sill, and dike bodies along northeast-trending steep-dipping faults in the Bingham Canyon area. Late-stage hydrothermal solutions altered the igneous and sedimentary rock hosts. Temperature-sensitive base and precious metals were precipitated in concentric temperature-sensitive zones about the central intrusion.

\section{Mercur (Camp Floyd) Mining District}

The Mercur mining district, in the western side of the southern Oquirrh Mountains (fig. 1), contains disseminated gold deposits in mid-Paleozoic Upper Mississippian Great Blue Limestone. The 
deposits are located in an eastward bow in the locally overturned Ophir anticline axis, a main fold on the upper plate of the imbricate Manning thrust (Tooker, 1987, and 1998). The regional stratigraphy of the rocks in the district were detailed by Tooker (1999) and Gordon and others (1999). Descriptions of the disseminated-gold ore deposits in the district are those by Kornze (1984), Kornze and others (1985), and Tafuri (1987).

The Mercur district was organized as a gold placer district in 1870 (Gilluly, 1932). Silver ores were discovered in 1873 , but the discovery of a cinnabar (mercury sulfide) vein in 1879 was the source of the district's name. Gold production became important in 1892 and continued intermittently until World War II. Production of low-grade, very-fine-grained, disseminated gold by the Getty Mining Company began in 1983. The Barrick Mining Company bought the property in 1985 (Kornze and others, 1985, and Tafuri, 1987). Production data for the Mercur district are listed in table 2.

Production of gold, mercury, minor silver, and lead from the Mercur district, shown in table 2, is based mainly on information by Kornze and others (1985), Shrier (verbal commun. 1993), and the U.S. Bureau of Mines (1993). About 1.1 million ounces of gold and minor mercury and silver were produced in the district during the period 1871-1945, and 767 thousand ounces of gold and minor silver and mercury were produced in the period 1983-1990. Production data for byproduct silver are not readily available, but in 19831984, for example, Faddies and Kornze (written commun., 1985) reported that $118,037 \mathrm{oz}$ of gold and $4,441 \mathrm{oz}$ of silver were produced.

Stratigraphy.--The main Mercur district ores occur in the upper part of the 97 m-thick Silveropolis limestone lower member of the Great Blue Limestone (Gordon and others, 1999). The Silveropolis limestone is composed of interbedded thin-bedded argillaceous limestone and shale. It is brown weathering and generally abundantly fossiliferous. Except where faulted locally, the member 
is overlain conformably by the Long Trail Shale Member of the Great Blue Limestone. The main productive stratigraphic horizons are in the upper part, in the "Mercur beds" of Kornze and others (1985). These beds include, in rising order, the silver chert jasperoid, magazine sandstone, a barren limestone, the Mercur bed, which contains the highest gold values and is composed of mudstone and grainstones rich in bryozoans, and finally, the upper limestone bed.

Structures.--The southern Oquirrh Mountains is composed of two adjoining through-going, southeast-striking main folds, a symmetrical (vertical axial plane) Pole Canyon syncline on the east side and the locally asymmetrical (axial plane locally tilted to the east) Ophir anticline on the west. The latter also has superimposed minor secondary folds, flexures, and small scale thrust imbrications along its western limb (Tooker, 1987). The stratigraphy and structures of these main folds differ markedly (fig. 9), and, east of Mercur, they are separated by the Manning (imbricate) thrust fault. The Pole Canyon syncline forms the higher, more rugged eastern side of the range and is composed of very competent, clastic, carbonate, and quartzitic rocks of the Butterfield Peaks Formation (Pennsylvanian) and underlying Manning Canyon Shale. (Pennsylvanian and Mississippian) The fold trends virtually uninterrupted to the southeastern end of the range (Tooker and Roberts, 1970). The faults in these rocks are generally wide-spaced, conjugate, steep-dipping normal faults with small displacement (figs. 9 and 10). Rocks in the Pole Canyon syncline are not mineralized near Mercur, and no igneous rocks occur in them there.

FIGURES 9 and 10, NEAR HERE

In contrast, a sinuous, much faulted and bent Ophir anticline with a short, steep-dipping eastern limb and long, gentle-dipping west limb, forms a topographically lower and structurally more complex western half of the range south of the Lion Hill tear fault (Tooker, 1987, cross section BB'). It is composed of Lower Paleozoic carbonate-rich sedimentary rocks that range from the Cambrian 
Tintic Quartzite to the Mississippian Great Blue Limestone (Tooker, 1999). These rocks are broken by close-spaced, complexly-faulted, conjugate, steep-dipping faults. East of Mercur in Manning Canyon, an overturned fold in Great Blue Limestone in the upper plate of the Manning thrust laps onto younger, gently east-dipping Manning Canyon Shale, which is the basal exposure in the Pole Canyon syncline (Tooker, 1987). The amount of movement on the Manning thrust, which is steep and dips west, can not be determined, but is probably small to moderate in comparison with that of the sole Midas thrust.

South of the Lion Hill tear fault, which is about $1 \mathrm{~km}$ south of Ophir, Utah (fig. 9), the flat, broad, asymmetrical shape of the Ophir anticline is believed to result from less-constrained movement on the Manning thrust on the south side of the Uinta trend buttress. The trace of the Ophir anticline axis is flexed eastward at Mercur. Smallamplitude secondary folds and minor imbricate thrusts occur on the western flank of the anticline. Abundant shales and argillaceous limestones in Lower Paleozoic strata provided slip surfaces in the subsurface strata beneath the Ophir anticline that facilitated the Manning thrust's crossing formational units as it rose in Manning Canyon against the more competent Pole Canyon syncline structure (Tooker, 1987; fig. 10).

An irregular pattern of local close-spaced, conjugate, normal and tension faults having small stratigraphic displacement were formed in the Ophir anticline. Intersecting sets of northwest- and northeast-striking steep-dipping normal faults in Mississippian-age carbonate rocks locally have a crackled map pattern. The northwest set gradually becomes nearly west-northwest striking as the Mercur district is approached from the north. Most of these are more closely spaced faults than those to the northwest or southeast along the fold. This may be due to the additional tensional stresses caused by bending the fold locally where it is arched and overturned on the Manning thrust east of Mercur. Tension and tear faults also were 
produced, and later local dilation was caused by the introduction of Tertiary intrusions.

Several small collapse structures also occur in the ore zone (Tooker, 1987). They strike nearly normal to the Ophir anticline, probably in response to increased tensional structures in that part of the fold, and are associated spatially with breccia pipes, one of which is mineralized (T.B. Faddies, verbal commun., 1988). The largest of these structures, the "Lulu syncline," probably was formed by a phreatic explosion and collapse during a late stage in the intrusion of the rhyolite porphyry sill. The local occurrence of intrusives and collapse structures normal to the bend in the Ophir anticline at Mercur are added evidence of the tensional fractures in sedimentary rocks in a thrust-thinned part of the upper plate of the Manning thrust fault.

Intrusives.--The Ophir anticline is cut by small sill and dike intrusions composed of finely crystalline rhyolite and rhyolite porphyry. They trend westward across the Ophir anticline to the range front and the West Mercur mining area. Recurrent exposures of these dikes trend northward to the Ophir mining district along imbricate thrusts and bedding faults.

There seems to be a close spatial association of the rhyolite sills, dikes, and plugs with mineralized sedimentary rock, but at present no evidence of mineralization in the rhyolite has been observed or of resetting of illite K/Ar (average) age of $152+/-4 \mathrm{Ma}$ for the gold-bearing hydrothermal event (Wilson and Parry, 1995).

Regional geologic studies of intrusives and their host rocks in western Utah may provide more definitive data. Based on conclusions of Camilleri and others, (1994), Miller and Hoisch (1995), and Elison (1995), the impact of the Elko orogeny was localized well west of Mercur. Allmendinger and Jordan (1981) suggest that the Jurassic intrusions and metamorphism provided a source of heat that initiated later Sevier thrust. It seems likely that the Sevier thrust 
produced the significant regional main folds observed in the Oquirrh Mountains. There are no known Jurassic intrusions in the vicinity of the Oquirrh Mountains. All of the mining districts in the Oquirrh Mountains are located in a continuous Sevier-age foreland thrust belt, but at variable distances from the Uinta trend, which is a potential crustal source structure for admitting Tertiary intrusions. Mercur is located farthest from the trend, its igneous rocks are younger than those overlying the trend at Ophir or Bingham (table 3 ), and the minerals associated in the deposits are formed at lower temperatures. The rhyolite dikes and stocks in the Ophir mining district connect with those at Mercur, thus providing a linkage with the higher-temperature Ophir deposits, which are closer to the Uinta trend.

Ore deposits.--Gold, silver, and mercury ores occur as bedded and irregular replacements, veins, fine-grained disseminations, and fissure deposits (Kornze and others, 1985). Alteration of the carbonate rocks initially was decalcification and introduction of quartz followed by development of kaolinite and sericite. Oxidized ores near the surface grade into hypogene sulfide ores in the deeper parts of mines. Gold mineralization conforms to bedding, but not to any particular bed (Kornze and others, 1985). The distribution of metals seems to be the result of variations in porosity, fracture density, and chemical composition in the beds, and a location near feeder faults.

It is uncertain whether the ores are the result of hydrothermal activity associated in some manner with the adjacent rhyolite intrusives, or their source at depth (Morris and Tooker, 1996), or whether, as suggested by Wilson and Parry, $(1990,1996)$, that the gold ores were mobilized from adjacent shales at depth in western Utah or eastern Nevada during the Late Jurassic orogeny in advance of very extensive regional Sevier-age thrusts and Tertiary intrusions in the Oquirrh Mountains. 
Conclusions.--The formation of gold ores in the Mercur mining district is based on the following factors. First, the structural and stratigraphic configurations of folds and thrust faults in the range (Tooker and Roberts, 1998) are most compatible with development during the Late Cretaceous Sevier orogeny. They are regionally extensive foreland structures, both north and south of the Mercur district. Second, ore deposits are spatially associated with a locallystressed part of the Ophir anticline on the upper plate of the Manning thrust. Third, Tertiary-age hydrothermal ores are trapped in variably porous, fractured, and overturned beds of the lower member of the host Great Blue Limestone at the bent, leading edge of the Manning thrust. The Great Blue Limestone also hosts ores in similar strata and structures in other mining districts or areas in the range. Fourth, there are breccia pipes, and evidence of phreatic activity in the Mercur area, which supposes hydrothermal activity.

A tentative hypothesis, which will require further field data in the region, is that the argillaceous lower Paleozoic rocks, and particularly those of the Great Blue Limestone, were metamorphosed at depth in the Utah-Nevada border hinterland during the Jurassic Elko orogeny. They were moved eastward and raised to their present foreland Bingham nappe site in the Oquirrh Mountains on the sole Midas and imbricate Manning thrusts. The tension structures developed in folds locally in the nappe at Mercur are comparable with those developed in other mining districts in the range. Because of the distance from the heat source underlying the Uinta trend, the Jurassic ages of clay-minerals in the Great Blue Limestone at Mercur apparently were not reset by the lowtemperatures that accompanied introduction of the Mercur rhyolites. Sedimentary host rocks were not altered to high-temperature mineral assemblages by hydrothermal solutions. Low temperature gold, cinnabar, silver, and base metal deposits produced were concentrated in the Silveropolis member. Similar assemblages also occur in the cooler peripheral hydrothermal deposits at Bingham (Rubright and Hart, 1968). Thus the possibility exists that Mercur 
gold and associated sulfide ores also may be of Tertiary-age hydrothermal origin.

\section{Ophir Mining District}

The Ophir mining district is located in Ophir Canyon on the western side of the southern Oquirrh Mountains about $6.0 \mathrm{~km}$ north of Mercur (fig. 1). The base-and precious metal deposits occur in replaceable carbonate-rich beds in Lower Paleozoic formations along the northern part of the Ophir anticline, mostly north of the Lion Hill tear fault, in the upper plate of the Manning thrust fault. The district was subdivided geographically by Gilluly (1932) into three parts: The main Ophir Hill area is on the north side of Ophir Canyon, the Lion Hill area is located on the south side of Ophir Canyon, and the Dry Canyon area lies northwest of Ophir Hill on the ridge above Ophir Canyon (fig. 11) at the head of Dry Canyon.

\section{FIGURE 11, NEAR HERE.}

The Ophir deposits were discovered in 1865 by soldiers stationed nearby, but surface outcrops of lead minerals in the Treasure Hill area in Ophir Canyon were known earlier by the Native American Indians (Gilluly, 1932). The town of Ophir was established in 1870, a district formed, and mining of oxidized lead-bearing surface lodes began. Production was from lead, silver, copper, and zinc bedded replacement, irregular replacement, and pipe, vein, and fissure ore bodies (table 2). Skarn ores occur in the deeper parts of the Ophir Hill mines and include lead, zinc, and silver sulfides and minor gold (Weintraub, 1957). Main development of most of the mines occurred in the mid- and late 1870s, and Gilluly (1932) relied mainly on oral and mining company reports because most of the mines were inactive or closed. According to Rubright (1978) most of the mines in the Dry Canyon and Lion Hill areas were exhausted in the late $1870 \mathrm{~s}$ and early $1880 \mathrm{~s}$. The district was intermittently active in the deeper parts of the Ophir Hill area until 1970, and was finally shut down in 1971 (Rubright, 1978). 
The main production from the Ophir Canyon area was from the Hidden Treasure and Ophir Hill mines (Gilluly, 1932). Records of early mining activity (1870-1901), which included some high-grade ores, are incomplete and existing records suggest that production may have been in the range of a few million dollars (Gilluly, 1932). Production from Ophir mining district in those years was combined with production from the Stockton mining district. Data from U.S.G.S. and U.S.B.M. records between 1902 and 1972 (table 2) indicate that lead was the principal metal recovered in the lower parts of the Ophir Hill area. Zinc, silver, gold, and copper were minor constituents of these ores. Potential ore reserves persisted below the lowest mined level at $1980 \mathrm{~m}$ in the Ophir Hill area (Rubright, 1978).

Stratigraphy.--The main sites of ore deposits are in replaceable shaly limestone and limestone horizons adjoining veins and in vein intersections of near-vertical, northeast-striking fissures. Favorable formations include the Cambrian-age Ophir Formation and Lynch Dolomite, the undivided Devonian-age Fitchville Formation and Pinyon Peak Limestone, the Mississippian-age Gardison Limestone (probably the most extensively replaced formation), Deseret Limestone, Humbug Formation, and Great Blue Limestone (Gilluly, 1932). Most recent mining activity was from veins and adjoining Lower Cambrian Ophir Formation skarns (Weintraub, 1957; Rubright, 1978).

Structures.--The Ophir anticline, the Manning and overlying imbricate thrusts, and a deep-reaching northeast-trending fracture system are the main host rock structures in the Bingham nappe at Ophir. North of the Lion Hill tear fault, the Manning thrust is offset northeastward and exposed in a side canyon opposite the mouth of the South Fork of Ophir Canyon. Here the Manning thrust also separates the faulted terrane in the overlying Ophir anticline from the competent Pole Canyon syncline. 
The Ophir anticline was lifted upward by the Manning thrust as it glanced steeply up and was stretched and draped over the Uinta trend buttress. The fold axis was bent downward as it plunged to the northwest. Its nearly symmetrical anticlinal form was preserved unlike its asymmetrically-shaped counterpart at Mercur (Tooker, 1987, cross sections $\mathrm{AA}^{\prime}$ and $\mathrm{BB}^{\prime}$ ). Imbricate thrusts were formed on its western flank. Bending the anticlinal axis across the Uinta trend zone at Ophir produced deep-reaching, northeast-trending, branching tension faults normal to the Ophir axis. Beds cut by the faults were not greatly offset laterally (Gilluly, 1932). Several of these tension fault structures intersected the Lower Paleozoic section, reaching more than 2,800 $\mathrm{m}$ down from surface exposures of the Great Blue Limestone to to an unknown depth below the Tintic Quartzite (Gilluly, 1932; and Tooker and Roberts, 1992).

The Lion Hill area is located in the upper plate of the imbricate Long Trail thrust fault, a local imbrication above the Manning thrust that lies east of the crest of the Ophir anticline, and immediately south of the Lion Hill tear fault. The location of the deposits was controlled mainly by northeast-striking branching fissures that were formed by tension in the Silveropolis member during the local bending of the fold axis. The deposits occurred in irregular pipelike bodies that formed along fault intersections in the Silveropolis limestone, and as blanket replacements of the limestone (Gilluly, 1932).

The Dry Canyon area, west of Bald Mountain, is on the thinned and arched upper plate of one of several imbricate thrusts on the western limb of the Ophir anticline in the upper plate of the Manning thrust. The thrust(s) bring lower Mississippian-age limestone over the Great Blue Limestone. Steep-dipping tear and normal faults segment the near-bedding thrust and provided channelways for the upward migration of ore-forming solutions into Mississippian sedimentary rocks. 
Intrusives.--The ore deposits in all areas in the Ophir mining district are closely associated with granodiorite or rhyolite intrusives (table 3). These igneous rocks gained entrance into the region along faults that seem to tap a Uinta-trend source. Granodiorite plugs, dikes, and sills occur spatially with deposits in the Lion Hill area. Monzonite-type dikes trend discontinuously along the faults overlying the Uinta trend between Bingham and Ophir (Tooker and Roberts, 1998).

Younger rhyolite and rhyolite porphyry intrusives are traced intermittently from Mercur to Ophir Hill and Dry Canyon. They are undated here, but presumed to be of ages comparable with their counterparts at Mercur (table 3). The dikes intersect northeaststriking, steep normal or tension faults in the Ophir Hill area, and then extend discontinuously into the Dry Canyon area along bedding and overlying imbricate thrust and normal faults. The Bald Mountain stock is the northern terminus of the rhyolite bodies. Weintraub (1957) believed that intrusion of the rhyolite/rhyolite porphyry dike and rhyolite breccias that cross the district postdate silication and predated the deposition of scheelite at Ophir Hill.

Ore deposits.--Oxidized base- and precious-metal ores in the upper parts of the Ophir Hill and adjacent mines occurred in pipes and vein fissures and as bedded or irregular replacements adjacent to through-going deep-reaching fissures. Ores in the deepest part of the Ophir Hill mine included galena, sphalerite, chalcopyrite, and pyrrhotite as the main ores minerals in the fissures, and as disseminations and replacements in adjoining limestones and skarns along bedding planes (Weintraub, 1957). Scheelite and wolframite, and bismuth and cadmium also occurred in fissures as disseminations in skarn ores in the Ophir Formation in the lower part of the Ophir Hill mines (Rubright, 1978). Skarns in the lower parts of the Ophir Hill mine are evidence of temperatures at depth nearly comparable with those occurring at Bingham (Weintraub, 1957; and Rubright, 1978) . 
Vein and replacement deposits at Lion Hill occurred in the upper part of the Mississippian Silveropolis limestone member of the Great Blue Limestone, immediately below the Long Trail Shale Member (Gilluly, 1932; Gordon and others, 1998; and Tooker, 1999). These deposits are closely associated with porphyritic granodiorite sills and dikes.

The vein and replacement deposits in the Dry Canyon area occur in Mississippian Gardison Limestone, Deseret Limestone, Humbug Formation, and the Silveropolis limestone member of the Great Blue Limestone, and Long Trail Shale Member of the Great Blue Limestone (Gillully, 1932 and Tooker, 1999). These deposits are spatially associated with rhyolite dikes and sills. Neither the Lion Hill or Dry Canyon area deposits were mined at depth. One presumes that exploration failed to find deeper extensions below the imbricate thrust faults that underlie the mines.

Conclusions.--The principal ore deposits in the Ophir mining district at Ophir Hill occurred in or adjacent to faults overlying the axis of the locally-stressed thrust-induced Ophir fold on the upper plate of the Manning thrust. The Ophir anticlinal axis was bent to the northwest as it moved east-northeast up against and draped over the Uinta trend buttress. Its northern part plunged to the northwest, and was overridden by several secondary thrusts. Tension across the stressed fold normal to its axis (across the Uinta trend buttress produced a northeast-trending, steep-dipping, deep-reaching, complex-branching fault zone. Sedimentary units across the faults have only moderate displacements. The thoroughgoing faults intersect a number of very replaceable, widely age-ranging lower Paleozoic carbonate horizons.

Magmatic materials moved up into fault openings in sedimentary rocks of the nappe at Ophir Hill, forming intrusions and accompanying hydrothermally altered host rocks and precipitation of the ores. The temperatures of solutions producing skarn ores in the deepest Cambrian formations appear to be comparable with those at 
Bingham. This places the Ophir Hill deposits near the center of the Uinta trend, overlying its heat source.

Smaller deposits or prospects occur in the Great Blue Limestone at the thinned leading edge of the Manning thrust also. These deposits occur in the peripheral Lion Hill and Dry Canyon areas of the Ophir mining district. They overlie small imbricate thrusts in the upper plate of the Manning thrust. These deposits also are spatially related to intrusive rocks

\section{Stockton (Rush Valley) Mining District}

Base- and precious-metal ores at Stockton (originally called the Rush Valley mining district), are located in the eastern part of the South Mountain nappe, east of the town of Stockton, Utah. These deposits occur in the folded and faulted upper plate of the Stockton thrust (figs. 3 and 12), which overlaps the Bingham nappe (Tooker and Roberts, 1992, and unpublished data). The South Mountain nappe is, in turn, overlapped from the west by the Tintic Valley thrust, which underlies the Stansbury Mountains (Tooker, 1983). Rush Valley deposits were discovered in 1864 by soldiers who were guarding stock on a government reservation in the area (Gilluly, 1932). Assays proved to be rich in silver, and a mining district was organized. Several local smelters treated the ores intermittently until 1880, after which ores were taken to smelters in the Salt Lake Valley. The geology of the district is reported by Mitchell (1908), Gilluly (1932), Tooker and Roberts (1992) and Tooker 1999). Geochemical studies are by Moore and others (1966) and geophysical data are reported by Mabey and others (1964).

\section{FIGURE 12, NEAR HERE}

Production data for metals recovered at Stockton during its early period were combined with data from the Ophir mining district (Table 2). Data from the district's later production, 1902-1970, are shown separately. Moore and others (1966) reported an 
unpublished communication (from E. H. Snyder, 1965) that since 1864 , the district produced more than $\$ 30$ million from about $1,200,000$ short tons of ore. Proportions of production values reported through 1927 include: Lead 75 percent; silver, 16 percent; zinc, 5 percent; gold 3 percent; and copper 1 percent.

Stratigraphy.--The limestone host rocks in the South Mountain nappe are nearly comparable in age, and, in a general way, are of similar composition but much thinner than those in the Bingham nappe in the Bingham mining district (fig. 7). The ores at Stockton occur in the Pennsylvanian Rush Lake and Salvation units of Tooker and Roberts (1992), which are composed mainly of calcareous quartzite and orthoquartzite with subordinate medium-bedded (6 to $24 \mathrm{~m}$ thick) limestones. The Salvation unit stratigraphy is correlated agewise with the Jordan and Commercial limestones in the lower part of the Pennsylvanian-age Clipper Ridge Member of the Bingham Mine Formation (Tooker and Roberts, 1970). However, the sedimentary rock units at Stockton do not include thick, cyclically repeated argillaceous, fossiliferous, arenaceous, and cherty limestones that typify the Butterfield Peaks Formation or the thick limestone beds that occur at the base of the Clipper Ridge Member (fig. 7, and Tooker and Roberts, 1992). Most ores occur in altered and replaced limestone beds adjacent to faults rather than in faults (Gilluly, 1932).

Structures.--The mining district is located in the eastern part of the nappe on the thinned upper plate wedge of the Stockton thrust in tightly folded, locally overturned, low-amplitude secondary folds. Emplacement of the nappe resulted in the formation of a broad arc, bending the folds, and creating a system of prominent, close-spaced, steep-dipping, branching, north-striking tension faults and bedding faults. Horizontal displacements of bedding across faults rarely exceeded $30 \mathrm{~m}$.

The western and more massive thicker part of the nappe on South Mountain, which exposes a single main west-northwest 
directed anticline, overlies the T.A.D. imbricate thrust (shown on fig. 3, and by Tooker and Roberts, 1998). The western part of the nappe is separated from the eastern part by the northeast-trending Rush Valley tear fault. Several warm springs occur along the trace of this fault. The anticline is bent west, becomes slightly overturned, and plunges beneath the Tintic Valley thrust. The fold is not as fractured as are those in the Stockton mining district and only a few unconnected intrusions occur along the faults.

Intrusives.--The ore-bearing structures in the Stockton mining district are spatially coextensive with intrusive porphyritic quartz monzonite and quartz monzonite pluton, dike, and sill bodies (table 2). Monzonite dikes, small plutons, and sills occur irregularly and discontinuously across the range from the Bingham district into the Stockton district (Tooker and Roberts, 1988, 1992; Tooker 1992) along northeast-trending faults. The largest body, the Stockton stock (Lufkin, 1965), lies at the edge of the Bingham nappe, but geophysical data imply that it is connected in the subsurface with smaller plugs or stocks in the Stockton district. These intrusive rocks lie along the projected trace of the Uinta trend. Formation temperatures of hydrothermal ore minerals at Stockton were lower than those at Bingham or Ophir Hill. Warm springs along the trace of the Rush Valley fault indicate that a heat source still exists along the trend.

Ore Deposits.--Ores are localized in vein deposits along the contacts of steep, northeast-trending fissures that cut favorable carbonate rocks, and as replacements in limestone horizons adjacent to the feeder faults (Gilluly, 1932 and Tooker and Roberts, 1992). Ores near the surface were mostly oxidized with local residual sulfide zones, but below $240 \mathrm{~m}$., the ores were mostly sulfides of lead, zinc, copper, and silver and some gold. Apparently minable ore deposits do not persist much below the basal Stockton thrust. The last working mine, the Ben Harrison (New Sockton) mine, was closed in 1972. Although the district currently is inactive, it has been the site of recent exploration for Mercur-type disseminated gold. 
Conclusions.--The South Mountain nappe is separated from the Bingham nappe by the Soldier Creek (tear) fault (Tooker, 1999). The thrust fault-induced fold and tensional fault structures in the Stockton mining district, in the eastern part of the South Mountain nappe, are similar to those in districts elsewhere in the Oquirrh Mountains. The nappe consists of a thinned wedge that rode obliquely onto a buttress formed by the Bingham nappe and underlying Uinta trend. The nappe is folded, locally overturned, and stretched where the fold axes are bent. Tension faults formed in stretched parts of fold became the locus for intrusives and alteration by hydrothermal solutions. Limestone beds intersected by these faults were altered, and locally replaced by sulfides. Ore deposits were not deep-reaching and seem to be restricted to the upper plate of the Stockton thrust. They are comparable in composition with base metal deposits that occur in the upper reaches of the Ophir mining district. No high-temperature skarns are found.

The western part of the nappe consists of a main fold on the imbricate T.A.D. thrust. It was not thinned, greatly stretched, or much faulted as it overran the unexposed eastern part of the South Mountain nappe on the Stockton thrust. Igneous rock intrusions and hydrothermal alteration were restricted in the western part of the nappe. No ore deposits formed here.

\section{Barneys Canyon and Melco Mining Areas}

The Barneys Canyon-Melco deposits are located $8 \mathrm{~km}$ north of the Bingham Canyon mine on the east side of the Oquirrh Mountains (figs. 3 and 13). The sediment-hosted disseminated gold deposits, which occur in the Flood Canyon unit of Tooker and Roberts (1988), contain minor silver, and were recognized and developed by Kennecott (Babcock and others, (1995) after completion of the author's field studies. However, this was a known mineralized area, based on numerous small adits, shafts, and prospect pits (Tooker, 1999). 
Gold production at Barneys Canyon began in 1989. Babcock and others, (1995) and Presnell and Parry (1995) considered that the disseminated gold deposits are part of the Bingham mining district. U.S.G.S/U.S.B.M. production data are shown in Table 2. Gunter and others (1990) estimated that the deposit contained 8.5 million metric tons averaging $1.6 \mathrm{~g} / \mathrm{t}$ gold. Babcock and others (1995) reported that $503,000 \mathrm{oz}$ were produced by 1993 , with a reserve of $392,000 \mathrm{oz}$. The Melco deposit is considered to contain an additional 196,000 oz. reserve (Gunter and others, 1990).

Stratigraphy.--The upper part of the Barneys Canyon deposit was discovered in an altered down-dropped klippen cap of fossiliferous Grandeur Member of the Park City Formation of Permian age, a part of the Rogers Canyon nappe emplaced over the Pass Canyon nappe (Tooker and Roberts, 1970, 1971). However, the main part of the Barneys Canyon deposit lies in the underlying Permian Flood Canyon unit of Tooker and Roberts (1988). [These host formations were designated by Presnell and Parry (1996) as the Grandeur Member of the Park City Formation and Kirkman-Diamond Creek Sandstone.] The deposit host rocks consist of interbedded fossiliferous, arenaceous, and dolomitic limestones, dolomite, shale, phosphorite, and chert in the folded, upper part of the Pass Canyon nappe. Gunter and others (1990), Babcock and others (1995), and Presnell and Parry (1996) provide more detailed geologic information about the Barneys Canyon and nearby Melco deposits.

FIGURE 13, NEAR HERE.

Structures.--Regional mapping indicates two formational units in the Pass Canyon nappe, both of which are separated by thrust faults. The folded lower Permian Dry Fork unit of Tooker and Roberts (1988) overlies an unexposed sole thrust fault. The Flood Canyon unit of Tooker and Roberts (1988), which hosts the Barneys Canyon and Melco deposits, is characterized on the northwest by tightly bent, close-spaced, low-amplitude, overturned folds on the 
upper plate of an imbricate thrust fault. Numerous local thrust imbrications with small displacements occur between tear faults. Local alteration of the Permian-age carbonate rocks is present in these displaced units. Refolding of tight isoclinal folds is attributed to later overriding nappe plates (Tooker, 1998). Structures in the eastern part of the nappe, are farther away from the highest westernmost part of the buttress west of Nelson Peak. In the deposit occurrence area, the folds are less fragmented and altered, but locally are overturned and their northeast-trending axial planes dip southeast (fig. 13). The leading edge of the thrust fault against the Uinta trend buttress is concealed by a northeast-trending, steep normal fault that drops the Erda Formation in the Rogers Canyon nappe into contact with the Flood Canyon unit. The southern margin of the Pass Canyon nappe is concealed beneath the Bingham nappe (Tooker and Roberts, 1998).

Ore Deposits.--The gold ores, as described by Presnell and Parry (1996), are sediment-hosted disseminated deposits that occur mainly in carbonates and sandstones in the Flood Canyon unit. Hydrothermal alteration of the host rocks included decalcification, silicification, and argillization. Gold was accompanied by pyrite, marcasite, minor arsenic sulfides and the trace elements, $\mathrm{As}, \mathrm{Sb}, \mathrm{Hg}$, $\mathrm{Ba}$, and $\mathrm{Tl}$. Fluid inclusions in quartz and barite and a lack of pyrophyllite indicated a maximum pressure of 700 bars and a temperature of $278^{\circ} \mathrm{C}$. The main ore body in the Barneys Canyon deposit was nearly stratabound, occurring along the contact zone between dolomite and sandstone, and seems to be concentrated along a northeast-trending fault zone (Gunter, and others, 1990, Babcock and others, 1995, and Presnell and Parry, 1995).

Intrusives.--Igneous intrusives are not found in the Barneys Canyon or Melco deposits; however, an altered porphyritic monzonite dike occurs in the vicinity, west of the Melco deposit

Conclusions.--Geologic evidence from a summary map of the Oquirrh Mountains (Tooker and Roberts, 1998), and the regional 
geologic setting, (Tooker, 1999), leads to the belief that the folded and faulted nappe structures were formed over the Uinta trend basement buttress during the Severe orogeny. The Permian stratigraphy is unique to the Pass Canyon nappe. It most resembles that in the Timpanogos nappe in the Wasatch Mountains and may be detached, thinner distal part of that nappe stranded in the Oquirrh Mountains by the Uinta trend buttress. The spatial association, if any, of ore deposits with sparse scattered Tertiary intrusive rocks in the nappe is not clear. The Barneys Canyon-Melco deposits lie on the northern periphery of the Uinta trend, and, like the deposits at Mercur, lie some distance away from the main Bingham intrusions and mineral deposition centered over the Uinta trend.

The production of folded thrust structures in the Barneys Canyon deposit was attributed by Babcock and others, (1995), Wilson and Parry, (1995), and Presnell and Parry, (1995) to the Jurassic-age (Elko) orogeny, based on their observations of $\mathrm{K}-\mathrm{Ar}$ ages of illite in fault clays. And, as at Mercur, they believed that gold mineralization at Barneys Canyon was derived from Middle and Late Jurassic plutonism and contact metamorphism of adjacent sedimentary rocks resulting from a compressional event in eastern Nevada and northwestern Utah. However, Camilleri and others (1994), Elison (1995), and Miller and Horsch (1995) report only local thrusting resulting from this Jurassic event. Thus, the attribution of extensive thrust-fault folds of Jurassic age in the Oquirrh Mountains seems problematical in terms of regional geologic relations noted earlier.

The author's hypothesis for the thrust-fault localization of ore deposits is less clearly demonstrated here than in other parts of the Oquirrh Mountains because structures resulting from later-formed overlapping nappes conceal critical contacts. However, the geologic structures elsewhere in the Oquirrh Mountains are a direct link in an extensive Sevier-age fold terrane stretching from Alaska to Mexico. The author believes that insertion of Jurassic thrust structures in the Oquirrh Mountains in the midst of an otherwise regionally extensive Sevier thrust terrane is not a tenable conclusion. It does seem 
possible that regional metamorphism produced Jurassic-age illites in the hinterland during deep burial and coincident with the intrusion of Jurassic-age plutons prior to the movement of the nappes eastward as part of Sevier-age thrusts. This Jurassic geochemical imprint is preserved only in the rocks at a distance from the main Tertiary intrusions along the Uinta trend, which destroyed the record of the earlier metamorphism. Until this problem is satisfactorily resolved, the uncertainty of origin for the Barneys Canyon-Melco (and Mercur) ore deposits remains. In the meantime, the author's tentative conclusions seem to be most reasonable possibilities for the origin of ore deposits in the Oquirrh Mountains.

\section{CONCLUSIONS}

The occurrences of base- and precious-metal mining districts in Oquirrh Mountains nappes are considered in the context of their regional geologic setting. Their occurrence is believed to depend on the conjunction of interacting geologic events over a period from the Precambrian to Quaternary. (1) An active basement Uinta trend fault-zone lineament were formed in the Precambrian craton. Reactive carbonate Paleozoic sedimentary rocks resulting from erosion of the craton or Antler highland were deposited in the main hinterland areas. (3) Low temperature metamorphism of deeply buried clay-bearing sediments in the hinterland imprinted a Jurassic age in illite in clay-rich (Mississippian) sedimentary rocks. (4) Late Cretaceous thrust faults moved nappes composed of Paleozoic sedimentary rocks from the hinterland into foreland areas such as the Oquirrh Mountains. Fault structure openings were formed locally in the folded sedimentary rocks. (5) Tertiary igneous bodies moved up from the Uinta trend basement zone into faulted and fractured structures. Hydrothermal alteration followed in and peripheral to the intrusives, and ore minerals were precipitated. (6) Finally, Quaternary uplift and erosion unroofed the deposits.

Late Cretaceous-age thrust faults of the Sevier orogeny brought five nappes eastward to their Oquirrh Mountains foreland sites 
against an uplifted Uinta trend basement buttress. Mining districts are clustered in three of the nappes that overlie or are on the periphery of the Uinta trend craton zone. The principal common thrust-related structures that typify the mining districts include bent, arc-stressed, asymmetric-shaped, locally-overturned folds, and steep-dipping, branching tension and tear faults developed normal to the fold axes by sole and/or imbricate thrust faults on the thinned, leading edges of nappe wedges rising against the basement Uinta trend buttress.

These conclusions are based on the following observations and interpretations of regional and Oquirrh Mountains geology:

(1) A mobile, east-west-trending basement lineament in the craton, the Uinta trend, separated the Paleozoic depositional area into two parts, the Oquirrh and Sublette basins. Contrasts are observed between the sedimentary strata formed in the Sublette basin and those formed in the Oquirrh basin. Clean, well-sorted clastic and precipitated quartz- and carbonate-rich craton-derived sedimentary materials from the east characterize Oquirrh basin rocks. The Sublette basin sedimentary rocks commonly consist of unsorted sedimentary materials and volcanic debris derived from a western Antler highland oceanic source area, mixed with well-sorted sedimentary materials typical of a cratonal source area. Occasional local uplift along the Uinta trend produced coarse clastic debris in some of the sedimentary rocks in the Pass Canyon nappe, which seems to represent an intermediate deposition site between the two main basins.

(2) A thick sequence of Paleozoic-age sedimentary rocks accumulated in the hinterland as the basins subsided. Subsequent regional metamorphism in the area occurred during the Late Jurassic Elko orogeny imprinting a Jurassic age on contained clay minerals.

(3) Decollement during the Late Cretaceous Sevier orogeny moved five sedimentary rock nappes on sole thrust faults from 
different parts of the hinterland basins eastward to their foreland sites, forming the present Oquirrh Mountains

(4) The site of the Oquirrh Mountains lay over an uplifted part of the Uinta trend, forming a buttress over which the nappes were individually draped and structurally deformed in sequence. The five nappes are recognized by unique fold patterns and their stratigraphic characteristics.

(5) The nappes were folded as they piled up against the Uinta trend buttress. Tensional, normal, and tear faults as well as imbricate thrusts were developed locally along the thinned, leading margin of the thrust where folds are arched or bent. Some of the folds locally were overturned along the front edges of the rising nappe.

(6) The mobile Uinta trend structure tapped crustal sources of magma, directing them up into the structurally-prepared host rocks in the nappes directly overlying the trend. Fault openings developed in most-stressed, tightly-folded and faulted parts of thrust terranes provided conduits for the upward movement of Tertiary intrusives and subsequent hydrothermal ore-bearing solutions.

(7) Ore deposits developed locally at unusually stressed sites in thinned, tight, arc-folded, well-faulted hanging wall portions of the lead edges of thrust faults that underlie (or are imbricate thrust faults within) individual nappes.

(8) Ore deposits in the Oquirrh Mountains nappes are zoned in terms of their compositions, and sized by their locations in respective nappes. A large concentration of zoned porphyry copper and baseand precious-metal deposits in the Bingham mining district is colocated in and about the largest altered intrusive porphyry stocks and dikes in the range. The intrusive magma moved directly from its Uinta trend source into locally-stressed, open structures in favorable stratigraphic units and fractured intrusives in the Bingham 
nappe. Elsewhere in the range, smaller, mostly lower-temperature, geochemically less complex base- and precious-metal ore deposits, which are spatially co-located with smaller intrusive dike and sill bodies, occur in thrust-fault stressed structural and stratigraphic sites in nappes. These nappes overlap the thick stratigraphic Bingham nappe. The intrusives and hydrothermal solutions were unable to produce complex Bingham-size types of deposits. They dissapated their chemical and thermal energies by having to work up through the thicker, structurally less-favorable parts of the Bingham nappe that separated them from the Uinta trend on the western side of the Oquirrh Mountains. Late-stage vein and native gold ores occur in the cooler peripheral zone of the greater Bingham mining district. Disseminated ores of gold and silver also are located farther from the Uinta trend in the Mercur and Barneys Canyon areas.

(9) The puzzling Jurassic age of altered clay minerals in Paleozoic carbonate rocks found in Cretaceous-age Sevier structures in the Barneys Canyon and Mercur mining districts, well away from the Uinta trend, seems to be best explained as preservation in a lower-temperature environment of Tertiary intrusions and hydrothermal solutions. These were unable to reset the Jurassic ages of the clays.

(10) Alteration of carbonate rocks along veins and in replaced carbonate rocks in the upper levels of mines overlying the Uinta trend includes silicification and marblization. The deeper ores directly overlying the Uinta trend at Bingham and Ophir are associated with skarn and hornfels alteration and the replacement of carbonates and shales.

(11) At Bingham, copper-molybdenum ores occur mainly in fractures in and adjacent to the Bingham and Last Chance stocks. Base- and precious-metal ores occur in peripheral zones in veins and replacements in adjoining carbonate sedimentary rocks. Disseminated gold ores at Mercur occur in fractures and as replacements in the folded lower member of the Great Blue 
Limestone. The base- and precious-metal vein and replacement ores in the Ophir Hill area seem to be peripheral to central, deep-reaching, thrust-related tensional faults in veins and replacements in numerous carbonate horizons in lower Paleozoic formations. Deposits in the Lion Hill and Dry Canyon areas are located on the folded and faulted Mississippian carbonate formations in the upper plates of imbricate thrusts. Apparently their ores do not persist at depth. The deposits at Stockton, are fault controlled in Pennsylvanian sedimentary rocks above the Stockton thrust and are co-located with dikes and plugs; they overlie a large unexplored stock.

(12) The trace of the Uinta trend zone in the Oquirrh Mountains is also the site of continued uplift during the Tertiary and Quaternary. Erosion unroofed the deposits and resulted in providing large concentrations of coarse clastic debris along the margins of the Oquirrh Mountains that overlay the Uinta trend. That was the source of detrital materials redistributed locally to form the Lake Bonneville shore-line deposits.

\section{ACKNOWLEDGMENTS}

I am most indebted to Ralph J. Roberts who conceived and developed the U.S.G.S. Bingham project and invited me to join it. $\mathrm{He}$ was called away to help develop a U.S. G.S. gold program before our field mapping was finished, entrusting me to complete studies in the Oquirrh Mountains. Numerous other Survey colleagues and company geologists cited herein have contributed greatly to the stratigraphic, structural, and geologic understanding of ore occurrences in the Oquirrh Mountains, and to the continuing growth of genesis concepts. I am also grateful to many investigators who preceded us in earlier days, also cited here, who made very important contributions to a growing body of knowledge about the geologic occurrence and origin of the Oquirrh Mountains mining districts. 


\section{REFERENCES CITED}

Allmendinger, R.W., and Jordan, T.E., 1981, Mesozoic evolution, hinterland of the Sevier orogenic belt: Geology, v. 9, no. 7, p. 308--313.

Allmendinger, R.W., Sharp, J.W., Von Tish, Douglas, Serpa, Laura, Brown, Larry, Kaufman, Sidney, Oliver, Jack, and Smith R.B., 1983, Cenozoic and Mesozoic structures of the eastern Basin and Range province, Utah, from COCORP seismic-reflection data: Geology, v. 11, no. 9, p. 523--536.

Armstrong, R.L., 1968, The Cordilleran miogeosyncline in Nevada and Utah: Bulletin Utah Geological and Mineral Survey, v. 78, p. 429--458. 1972, Low-angle (denudation) faults, hinterland of the Sevier orogenic belt, eastern Nevada and western Utah: Bulletin Geological Society of America, v. 83, no. 6. p. 1729--1754.

Atkinson, W.W., Jr., and Einaudi, M.T., 1978, Skarn formation and mineralization in the contact aureole at Carr Fork, Bingham, Utah: Economic Geology, v. 73, no. 7, p. 1326--1365.

Babcock, R.C., Jr., Ballantyne, G.H., and Phillips, C.H., 1995, Summary of the geology of the Bingham mining district, Utah, in Pierce, F.W. and Bolm, J.G., eds., Porphyry copper deposits of the American Cordillera: Tucson, Arizona, Arizona Geological Society Digest 20, p. 316--335.

Baker, A.A., Huddle, J.W., and Kinney, D.M., 1949, Paleozoic geology of north and west sides of Uinta Basin, Utah: Bulletin American Association of Petroleum Geologists, v. 33, no. 6, p. 1161--1197.

Bankey, Viki, and Campbell, D.L., 1989, Status of geophysical data base, in Stein, H.J., Bankey, Viki, Cunningham, C.G., Zimbelman, D.R., Brickey, D.W., Shubat, Michael, Campbell, C.G., and Podwysocki, M.H., Tooele $1 \times 2$ degree quadrangle, northwest Utah: a CUSMAP pre-assessment study: U.S. Geological Survey Open-File Report 89--467, p. 46-59.

Boutwell, J.M., 1905, Genesis of the ore deposits at Bingham, Utah: American Institute of Mining Engineers Transactions, v. 36, p. 541--580.

Bowman, J.R., Parry, W.T., Kropp, W. P., and Kruger, S.A., 1987, Chemical and isotopic evolution of hydrothermal solutions at Bingham, Utah: Economic Geology Bulletin, v. 82, no. 2, p. 395--428.

Bray, R. E., Lanier, George, and John, E.C., 1975, General geology of the open-pit mine, in Bray, R.E., and Wilson, J.C., eds., Guidebook to the Bingham mining district, Society of Economic Geologists, October 23, 1975: Bingham Canyon Utah, Kennecott Copper Corporation, p. 49--58.

British Petroleum Company, 1986, Financial and operating information, 19821986: Cleveland, Ohio, BP America, Inc. p. 112--114.

Brooks, J.E., 1956, Middle Paleozoic tectonic history of north-central and northwestern Utah [abs.]: Journal of Paleontology, v. 30, no. 4, p. 1009.

Bryant, Bruce, 1979, Reconnaissance geologic map of the Precambrian Farmington Canyon complex and surrounding rocks in the Wasatch Mountains between Ogden and Bountiful, Utah: U.S. Geological Survey Open-File Report 79-709, scale 1:50,000. 1988 Evolution and early Proterozoic history of the margin of the Archean continent in Utah, in Ernst, W.G., Metamorphism and crustal evolution of the western United States, Rubey Vol. VII: Prentice Hall, Englewood Cliffs, NJ, p. 431--445.

Cameron, D.E., and Garmoe, W.J., 1983, Distribution of gold in skarn ores of the Carr Fork mine, Tooele, Utah: Economic Geology, v. 82, no. 5, p. 1319--1333. 
Camilleri, P.A., Miller, D.M., Snoke, A.W., and McGrew, A.J., 1994, Mesozoic metamorphic architecture of the hinterland of the Sevier fold and thrust belt, northeast Nevada: Geological Society of America Abstracts with program, Cordilleran section, v. 26, n. 7, p. 43.

Coats, R.R., 1987, Geology of Elko County, Nevada: Nevada Bureau of Mines and Geology, Bulletin 101, 112 p.

Crittenden, M.D., Jr., 1961, Magnitude of thrust faulting in northern Utah: U.S. Geological Survey Professional Paper 424-D, p. D128--D131. 1963, New data on the isostatic deformation of Lake Bonneville: U.S. Geological Survey Professional Paper 454-E, 31 p.

Crittenden, M.D., Jr., Granger, A.E., Sharp, B.J, and Calkins, F.C., 1952 Geology of the Wasatch Mountains east of Salt Lake City: Utah Geological Society Guidebook to the Geology of Utah, v. 8, p. 1--37.

Eaton, G.P., 1979, Regional geophysics, Cenozoic tectonics, and geologic resources of the Basin and Range province and adjoining regions, in Newman, G.W., and Goode, H..D., eds., Basin and Range symposium and Great Basin field conference: Rocky Mountain Association of Geologists, Denver, CO., p. 11--40.

Eaton, G.P., Wahl, R.R., Prostka, H.J., Mabey, D.R., and Kleinkopf, M.D., 1978, Regional gravity and tectonic patterns: Their relation to late Cenozoic epeirogeny and lateral spreading in the western Cordillera, in Smith, R.B. and Eaton G.P. eds, Cenozoic tectonics and regional geophysics of the western Cordillera: Geological Society of America Memoir 152, p.51--91.

Elison, M.W., 1995, Causes and consequences of Jurassic magmatism in the northern Great Basin: Implications for tectonic development, in, Miller, D.M. and Busby, Cathy, eds., Jurassic magmatism and tectonics of the North American Cordillera: Geological Society of America Special Paper 299, p. 249--266.

Erickson, A.J., Jr., 1976, The Uinta-Gold Hill trend: an economically important lineament, in Utah Geological Association Proceedings of the First International Conference on the new basement tectonics: Utah Geological Association Publication, no. 5, p. 126--137.

Field, C.W. and Moore, W.J., 1971, Sulfur isotope study of the "B" limestone and galena fissure ore deposits of the U.S. mine, Bingham mining district, Utah: Economic Geology, v. 66, no. 1, p. 48--62.

Gilluly, James, 1932, Geology and ore deposits of the Stockton and Fairfield Quadrangles, Utah: U.S. Geological Survey Professional Paper 173, 171 p.

Gordon, Mackenzie, Jr. and Duncan, H.M., 1970, Biostratigraphy and correlation, in Tooker, E.W. and Roberts, R.J., Upper Paleozoic rocks in the Oquirrh Mountains and Bingham Mining District, Utah: U.S. Geological Survey Professional Paper 629-A, p. A38--A-69.

Gordon, Mackenzie, Tooker, E. W., and Dutro, J.T., Jr., 2000, Geology of the type locality for the Great Blue Limestone in the Oquirrh Mountains, Utah: U.S. Geological Survey Open-File Report 00-012, 66 p.

Gunter, W.L., Hammitt, J.W., Babcock, R.C., Gibson, T.R., and Presnell, R.D., 1990, Geology of the Barneys Canyon and Melco gold deposits, Salt Lake County, Utah, in Hausen, D.M., ed., Gold 90: Proceedings of the Gold '90 symposium, Salt Lake City, Utah: Littleton, Colo., Society for Mining, Metallurgy, and Exploration, p. 41--50. 
Hamilton, Warren, 1988, Tectonic setting and variations with depth of some Cretaceous and Cenozoic structural and magmatic systems of the western United States, in Ernst, W.G. ed., Metamorphism and crustal evolution of the western United States, Rubey Vol VII: Prentice Hall, Englewood Cliffs, NJ, p. 1--40.

Hayes, K.H., 1976, A discussion of the geology of the southeastern Canadian Cordillera and its comparison to the Idaho-Wyoming-Utah fold and thrust belt, in J Gilmore Hill, ed., Geology of the Cordilleran hingeline: Rocky Mountain Association of Geologists 1976 symposium, Denver, CO., p. 59--82.

Hunt, R.N., 1924, The ores in the limestones at Bingham, Utah: Transactions of the Institution of Mining and Metallurgy Engineers, v. 70 , p. $856--883$.

James, A.H., Smith, W.H., and Bray, R.E., 1961, Bingham district-a zoned porphyry ore deposit, in Cook, D.R., ed., Geology of the Bingham mining district and northern Oquirrh Mountains: Utah Geological Society Guidebook 16, p. $81--100$

James, L.P., 1978, The Bingham copper deposits, Utah, as an exploration target: History and pre-excavation geology: Economic Geology, v. 73, no. 7, p. $1218--1227$

, 1982, Sulfide ore deposits related to thrust faults in northern Utah: Salt Lake City, Utah, Utah Geological Association Publication no. 10, p. 91-100.

John, E.C., 1978, Mineral zones in the Utah Copper orebody: Economic Geology, v. 73 , no. 7 , p. $1250--1269$.

John, D.A., 1989, Evolution of hydrothermal fluids in the Park Premier Stock, central Wasatch Mountains, Utah: Economic Geology, v. 84, n. 4, p. 879-902.

King, P.B., 1976, Precambrian geology of the United States--an explanatory text to accompany the Geologic Map of the United States: U.S. Geological Survey, Professional Paper 902, 85 p.

Kornze, L.D., 1984, Geology of the Mercur gold mine, in Johnson, J.L., ed., Bulk mineable precious metal deposits in the western United States: Guidebook for field trip, Geological Society of Nevada, Reno, NV., p. $381--389$.

Kornze, L.D., Faddies, T.B., Goodwin, J.C., and Bryant, M.A.., 1985, Geology and geostatistics applied to grade control at the Mercur gold mine, Mercur, Utah: American Institute of Mining and Metallurgical Engineers Preprint 84-442, 21 p.

Lanier, George, compiler, 1978, Geologic map of the Bingham mine, Bingham Canyon, Utah, in Lanier, and others, 1978, General geology of the Bingham mine, Bingham Canyon, Utah: Bingham, Utah, Kennecott Copper Corporation, scale 1:9,600.

Lanier, George, Raab, W.J., Folsom, R.B., and Cone, S., 1978, Alteration of equigranular monzonite, Bingham mining district, Utah: Economic Geology, v. 73, no. 7, p. 1270--1286.

Lufkin, J.L., 1965, Geology of the Stockton stock and related intrusives: Brigham Young University research studies, Geologic series, v. 12, p. $149--164$.

Mabey, D.R., Zeitz, Isidore, Eaton, G.P., and Kleinkopf, M.D., 1978, Regional magnetic patterns in part of the Cordillera in the western United States, in Smith, R.B. and Eaton, G.P., eds., Cenozoic tectonics and regional geophysics of the western Cordillera: Geological Society of America Memoir 152, p. 53--106. 
Mabey, D.R., Crittenden, M.D., Jr., Morris, H.T., Roberts, R.J., and Tooker, E.W., 1964, Aeromagnetic and generalized geologic map of part of NorthCentral Utah: U.S. Geological Survey Geophysical Investigations Map GP-422, scale 1:250,000.

Mitchell, H.G., 1925, A geological report on the Dry Canyon division of the Ophir mining district, Utah: PhD dissertation, Sanford University, Stanford, CA, 58 p.

Miller, D.M. and Horsch, T.D., 1995, Jurassic tectonics of northeastern Nevada and northwestern Utah from the perspective of barometric studies, in Miller, D.M., and Busby, Cathy, eds., Jurassic magmatism and tectonics of the North American Cordillera: Geological Society of America Special Paper 299, p. 267--294.

Moore, W.J., 1973a, Preliminary geologic map of the western Traverse Mountains, Salt Lake and Utah Counties, Utah: U.S. Geological Survey Miscellaneous Field Studies Map MF-490, scale 1:24,000. , 1973b, Igneous rocks in the Bingham mining district, Utah: U.S. Geological Survey Professional Paper 629-B, $42 \mathrm{p}$. , 1973c, A summary of radiometric ages of igneous rocks in the Oquirrh Mountains, north-central Utah: Economic Geology Bulletin, v. 68 , no. 1 , p. $97--101$.

Moore, W.J., Curtin, G.C., Roberts, R.J., and Tooker, E.W., 1966, Distribution of selected metals in the Stockton District, Utah: U.S. Geological Survey Professional Paper 550-C, p. C197--C205.

Moore, W.J. and Nash, J.T., 1974;, Alteration and fluid inclusions studies of the porphyry copper ore body at Bingham, Utah; Economic Geology Bulletin, v. 69, no. 5, p. 631--645.

Moore, W.J., and McKee, E.H., 1983, Phanerozoic magmatism and mineralization in the Tooele $1 \times 2$ degree quadrangle, Utah, in Miller, D.M., Todd, V.R., and Howard, K.A., eds., Tectonic and stratigraphic studies in the eastern Great Basin: Geological Society of America Memoir 157, p. 183--190.

Morris, H.T., 1983, Interrelations of thrust and transcurrent faults in the central Sevier orogenic belt near Leamington, Utah, in Miller, D.M., Todd, V.R., and Howard, K.A., eds., Tectonic and stratigraphic studies in the eastern Great Basin: Geological Society of America Memoir 157, p. $183--190$.

Morris, H.T. and Tooker, E. W., 1996, Characterization and dating of argillic alteration in the Mercur gold district, Utah-a discussion: Econ. Geology Bulletin, v. 91, p. 477--479.

Oriel, S.S., and Armstrong, F.C., 1966, Times of thrusting in the Idaho-Wyoming thrust belt--Reply: Bulletin American Association of Petroleum Geologists, v. 50, no. 12, p. 2614--2621.

Peters, W.C., James, A.H., and Field, C.W., 1966, Geology of the Bingham Canyon porphyry copper ore body at Bingham, Utah, in Titley, S.R., and Hicks, C.L., eds., Geology of the porphyry copper deposits, southwestern North America: Tucson, Ariz., University of Arizona Press, p. 165--175.

Peterson, J.A., 1977, Paleozoic shelf-margins and marginal basins, western Rocky Mountains--Great Basin, United States, in Twenty-ninth annual field conference guidebook--1977; Wyoming Geological Association, p. $135--153$.

Presnell, Ricardo and Parry, W.T., 1995, Evidence of Jurassic tectonism from the Barneys Canyon gold deposit, Oquirrh Mountains, Utah, in Miller, E.M. and Busby, Cathy, eds. Jurassic Magmatism and tectonics of the North American Cordillera: Geological Society of America Special Paper 299 , p. $13--326$. 
Presnell, R.D. and Parry, W.T., 1996, Geology and geochemistry of the Barneys Canyon gold deposit, Utah; Economic Geology Bulletin. v. 91, n. 2, p. 273--288.

Price, R.A., 1989, The mechanical paradox of large overthrusts: Bulletin Geological Society of America, v. 100, no. 12, p. 1889--1908.

Reid, J.E., 1978, Skarn alteration of the Commercial Limestone, Carr Fork area, Bingham, Utah: Economic Geology Bulletin, v. _, n. _, p. 1315--1325.

Roberts, R.J., Crittenden, M.D., Jr., Tooker, E.W., Morris, H.T., Hose, R.K., and Cheney, T.M., 1965, Pennsylvanian and Permian basins in northwestern Utah, northeastern Nevada, and south-central Idaho: Bulletin American Association of Petroleum Geologists, v. 49, no. 11, p. 1926--1956.

Roberts, R.J., and Crittenden, M.D., Jr., 1973, Orogenic mechanism, Sevier orogenic belt, Nevada and Utah, in Dejong, K.A., and Sholten Robert, eds., Gravity and tectonics: New York, John Wiley and Sons, p. 409--428.

Roberts, R.J., and Tooker, E.W., 1969, Age and regional significance of conglomerate in the Newfoundland and Silver Island Mountains, Utah [abs.]: Geological Society of America Abstracts with Programs, pt. 5, p. 69.

Roedder, Edwin, 1971, Fluid inclusion studies on the porphyry-type ore deposits at Bingham, Utah, Butte Montana, and Climax, Colorado: Economic Geology Bulletin, v. 66, no.1, p. 98--120.

Rose, A.W., 1967, Trace elements in sulfide minerals from the Central district, New Mexico, and the Bingham district, Utah: Geochimica et Cosmochimica Acta, v. 31, p. 547--585.

Rubey, W.W. and Hubbert, M.K., 1959, Overthrust belt in geosynclinal area of western Wyoming in light of fluid-pressure hypothesis [Pt. II of Role of fluid pressure in mechanics of overthrust faulting]: Geological Society of America Bulletin, v. 70, no. 2, p.167--205.

Rubright, R.D., 1978, Geology of the Ophir district, Utah, in Shawe, D.R., and Rowley, P.D., eds., Field excursion C-2, Guidebook to mineral deposits of southwestern Utah: Utah Geological Association, Publ 7, p. 35--40.

Rubright, R.D., and Hart, O.J., 1968, Non-porphyry ores of the Bingham district, Utah, in Ridge, J.D., ed., Ore deposits of the United States, 1933-1967

[Graton-Sales volume]: New York, American Institutes of Mining and Metallurgical and Petroleum Engineers, v. 1, p. 886--907.

Sears, J.W., Graff, P.J., and Holden, G.S., 1982, Tectonic evolution of the lower Proterozoic rocks, Uinta Mountains, Utah and Colorado: Geological Society of America Bull. v. 93, no. 10, p. 990--997.

Sims, P.K., Ksvarsanyi, E.B. and Morey, G.B., 1987, Geology and metallogeny of Archean and Proterozoic basement terranes in the northern midcontinent, U.S.A.-an overview: U.S. Geological Survey Bulletin 1815, $51 \mathrm{p}$.

Smith, W.H., 1961, The volcanics of the eastern slopes of the Bingham districts in Cook, D.R., ed., Geology of the Bingham mining district and the northern Oquirrh Mountains: Utah Geological Society, Guidebook to the Geology of Utah, no. 16, p. 101--119.

Speed, Robert, Elison, M.W., and Heck, F.R., 1988, Phanerozoic tectonic evolution of the Great Basin, in Ernst., W.G., ed., Metamorphism and crustal evolution of the western United States, Rubey Vol. VII: Prentice Hall, Englewood Cliffs, NJ, p. 572--648.

Stewart. J.H., 1978, Basin-range structures in western North America: A review, in Smith, R.B., and Eaton, G.P., eds., Cenozoic tectonics and regional geophysics of the western Cordillera: Geological Society of America Memoir 152, p. 1--31 
Stewart, J.H., and Poole, F.G., 1974, Lower Paleozoic and uppermost Precambrian Cordilleran miogeocline, Great Basin, western United States in Dickinson, W.R., ed., Tectonics and sedimentation: Society of Economic Paleontologists and Mineralogists Special Publication no 22, p. $28--57$.

Stewart, J.H., Moore, W.J., and Zeitz. Isidore, 1977, East-west patterns of Cenozoic igneous rocks, aeromagnetic anomalies and mineral deposits, Nevada and Utah: Geological Society of America, Bulletin v. 87, no. 1, p. 67-77.

Stowe, C.H., compiler, 1975, Utah mineral industry statistics through 1973: Utah Geological and Mineral Survey Bulletin 1066, $121 \mathrm{p}$,

Swensen, A.J., 1975, Sedimentary and igneous rocks of the Bingham district [Utah], in Bray, R.E., and Wilson, J.C., eds., Guidebook to the Bingham mining district: Society of Economic Geologists, p. 21--39.

Tafuri, W.J., 1987, Geology and geochemistry of the Mercur mining district, Tooele County, Utah: PhD dissertation, University of Utah, Salt Lake City, 180 p.

Tooker, E.W., 1970, Radial movements in the western Wyoming salient of the Cordilleran overthrust belt: Discussion: Bulletin Geological Society of America, v. 81 , no. 11 , p. 3503--3506.

1971, Regional structural controls of ore deposits, Bingham mining district, Utah, U.S.A., in International Association of the Genesis of Ore Deposits, Tokyo-Kyoto: Tokyo, Japan, Meetings, papers, and proceedings, Geological Society of Minerals, Japan, Special Issue no 3, p. 67--81.

., 1983, Variations in structural style and correlation of thrust plates in the Sevier foreland thrust belt, Great Salt Lake area, Utah, in Miller, D.M., Todd, V.R., and Howard, K.A., eds., Tectonic and stratigraphic studies in the eastern Great Basin: Geological Society of America Memoir 157, p. $61--73$.

1987, Preliminary geologic maps, cross sections, and explanation pamphlet for the Ophir and Mercur Quadrangles, Utah: U.S. Geological Survey Open-File Report 87-152. scale 1:24,000.

, 1990, Gold in the Bingham district, Utah, in Shawe, D.R., ed., Geology of gold in the United States, gold in porphyry copper systems: U.S. Geological Survey Bulletin 1857-E, p. E1--E16. , compiler, 1992, Preliminary geologic map of the Lowe Peak 7 1/2minute quadrangle, Tooele, Utah, and Salt Lake Counties, Utah: U.S. Geological Survey Open-File Report 92-404, 13 p., scale 1:24,000.

1999, Geology of the Oquirrh Mountains, Utah: U. S. Geological Survey Open-File Report 99-571, 150 p.

Tooker, E.W., and Roberts, R.J., 1970, Upper Paleozoic rocks in the Oquirrh Mountains and Bingham mining district, Utah, with $a$ section on Biostratigraphy and correlation by Mackenzie Gordon Jr., and H.M. Duncan: U.S. Geological Survey Professional Paper 629-A, 76 p. 1971, Geology of the Garfield Quadrangle, Utah: U.S. Geological Survey Quadrangle Map, GQ-923, scale 1:24,000. , 1988, Preliminary geologic map, cross-sections, and explanation pamphlet for the Bingham Canyon Quadrangle, Salt Lake and Tooele Counties, Utah: U.S. Geological Survey Open-File Report 88-699, scale $1: 24,000$.

1992, Preliminary geologic map of the Stockton 7 1/2-minute quadrangle, Tooele County, Utah: U.S. Geological Survey Open-File Report 92-385, 22 p. scale 1:24,000. 
, compilers, 1998, Geologic map of the Oquirrh Mountains and adjoining South and West Traverse Mountain, Tooele, Utah, and Salt Lake Counties, Utah: U.S. Geological Survey, Open-File Map 98-581, scale $1: 50.000$.

U.S. Bureau of Mines, 1924-1993, in Mineral resources of the United States [annual] volumes for the years indicated: Washington D.C.

U.S. Geological Survey, 188301923, in Mineral resources of the United States [annual] volumes for the years indicated: Washington, D.C..

Warnaars, F.W., Smith, W.H., Bray, R.E., Lanier, George, and Shafiqullah, Muhammed, 1978, Geochronology of igneous intrusions and porphyry copper mineralization at Bingham, Utah: Economic Geology, v. 73, no. 7, p. $1242--1249$.

Webb, G.W., 1958, Middle Ordovician stratigraphy in eastern Nevada and western Utah: Bulletin American Association of Petroleum Geologists, v. 42 , no. 10 , p. $2335--2377$.

Weintraub, Judy, 1957, Mineral paragenesis and wall rock alteration at the Ophir mine, Tooele County, Utah: M.S. dissertation, University of Utah, Salt Lake City, Utah, 44 p.

Wilson, P.N. and Parry, W.T., 1990, Mesozoic hydrothermal alteration associated with gold mineralization in the Mercur district, Utah: Geology, v. 18, p. 866--869. 1995, Characterization and dating of argillic alteration in the Mercur gold district, Utah: Economic Geology Bulletin, v. 90, n. _, p. $1197-1216$.

1996, Characterization and dating of argillic alteration in the Mercur gold district, Utah--A reply: Economic Geology Bulletin, v. 91, n. _, p. 479--481. 


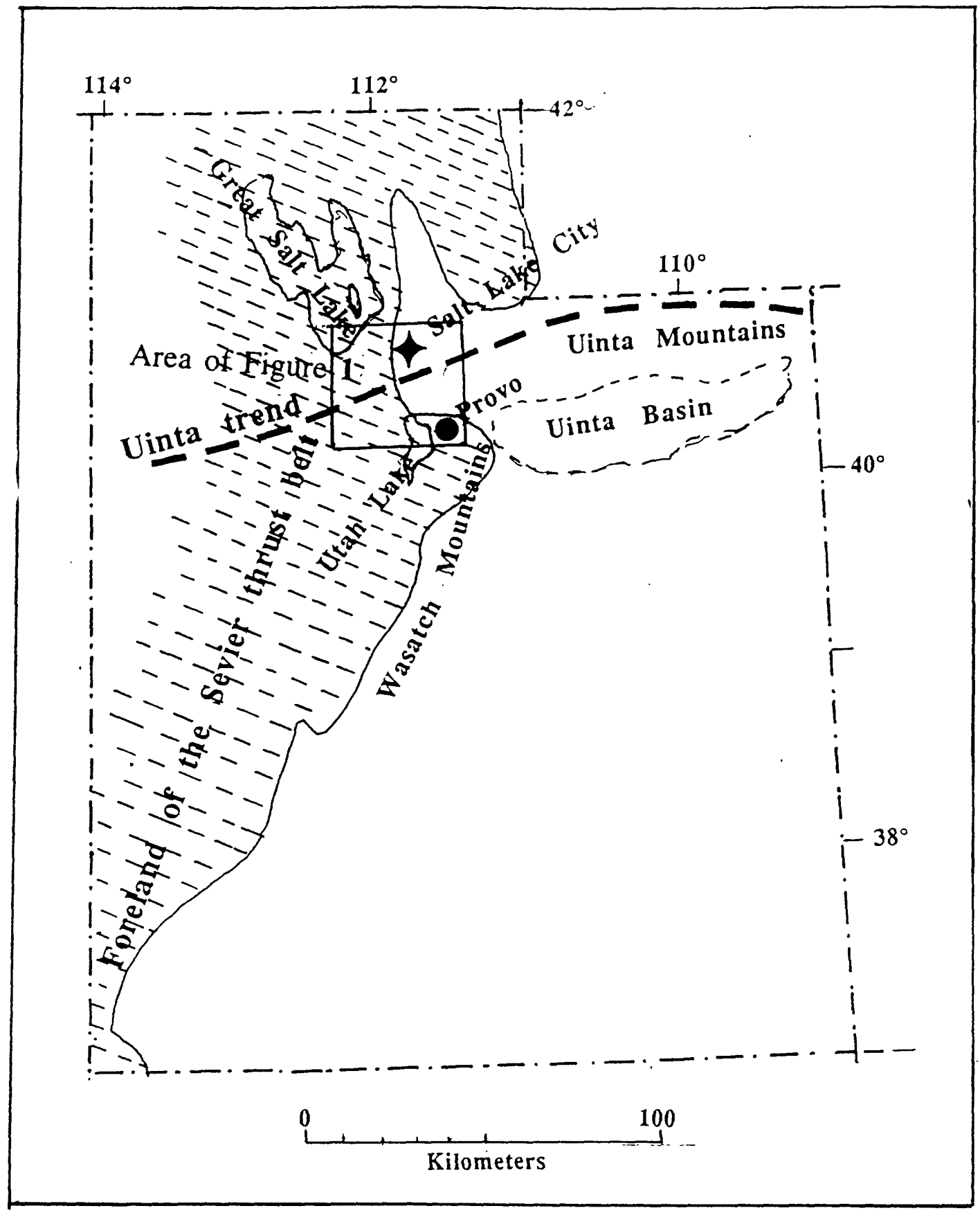

Figure 2--Foreland of the Sevier thrust belt (shaded), the trace of the inferred Uinta trend basement lineament, and the location of Figure 1, which includes the Oquirrh Mountains. 


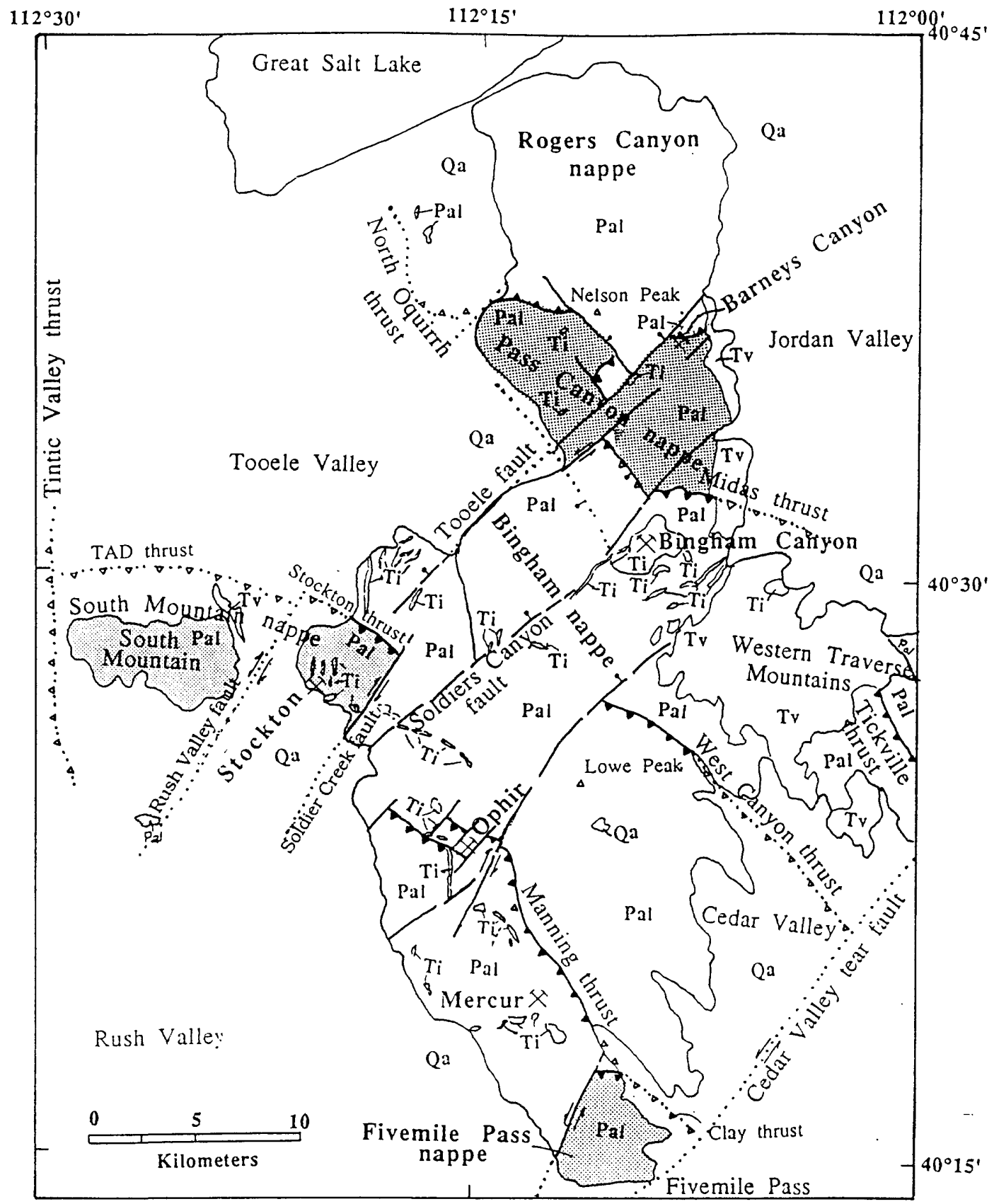

Figure 3--Location of the Oquirrh Mountains' nappes and the distribution of igneous rocks. Shaded nappe areas assist in differentiating the five nappes. Open thrust symbol indicates a concealed down-dropped thrust. Qa--unconsolidated sediments, undivided. Tr--volcanic rocks, undivided, Ti--intrusive rocks, undivided, and Pal--Paleozoic sedimentary rocks, undivided. 
Farnsworth Peak Quadrangle (Tooker and Roberts, 1971). Bingham Canyon Quadrangle (Tooker and Roberts, 1988. Stockion Quadrangle (Tooker and Roberts, 1992)

Lowe Peak Quadrangle (Tooker, 1992)

Ophir and Mercur Quadrangles i(Tooker, 1987)

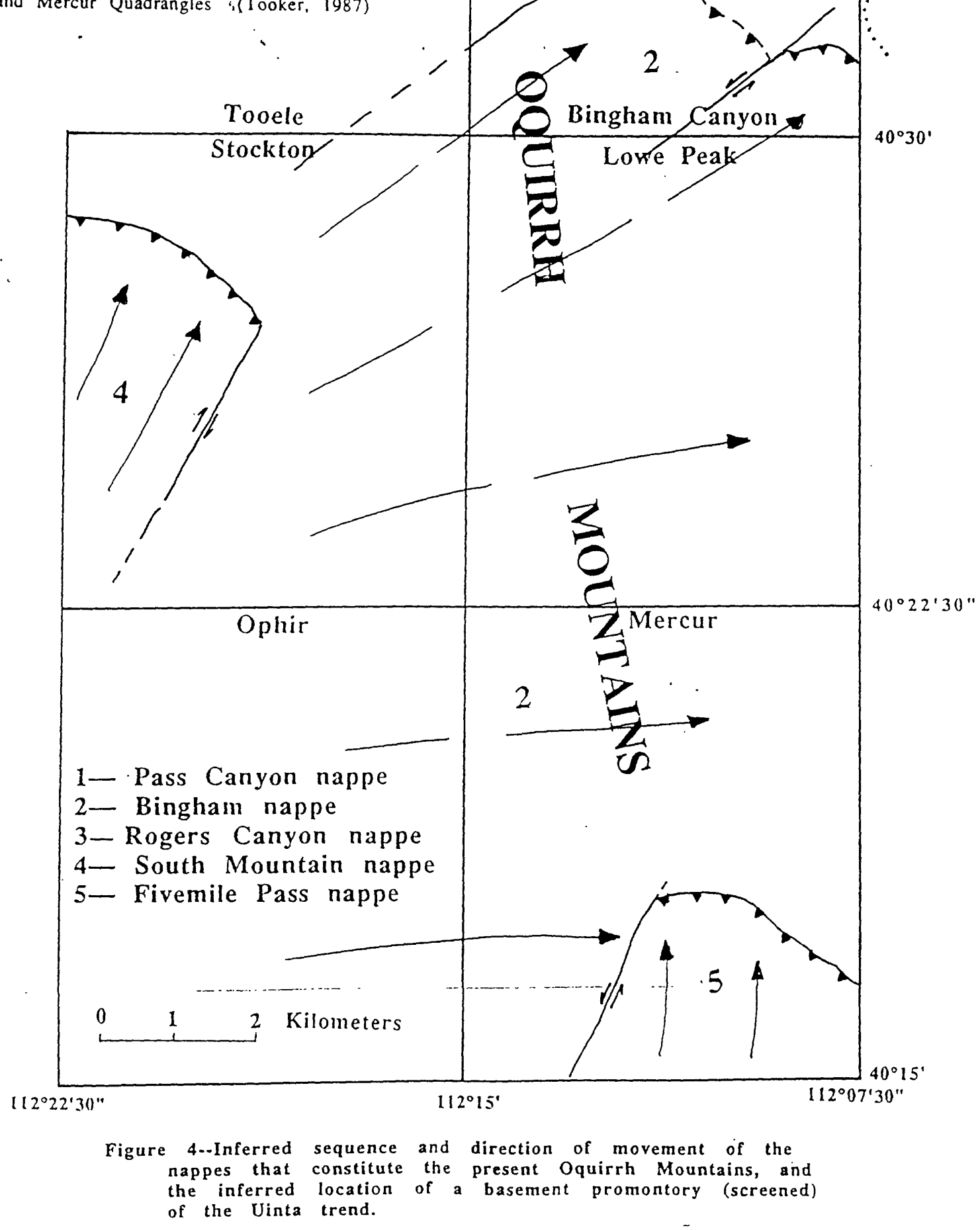




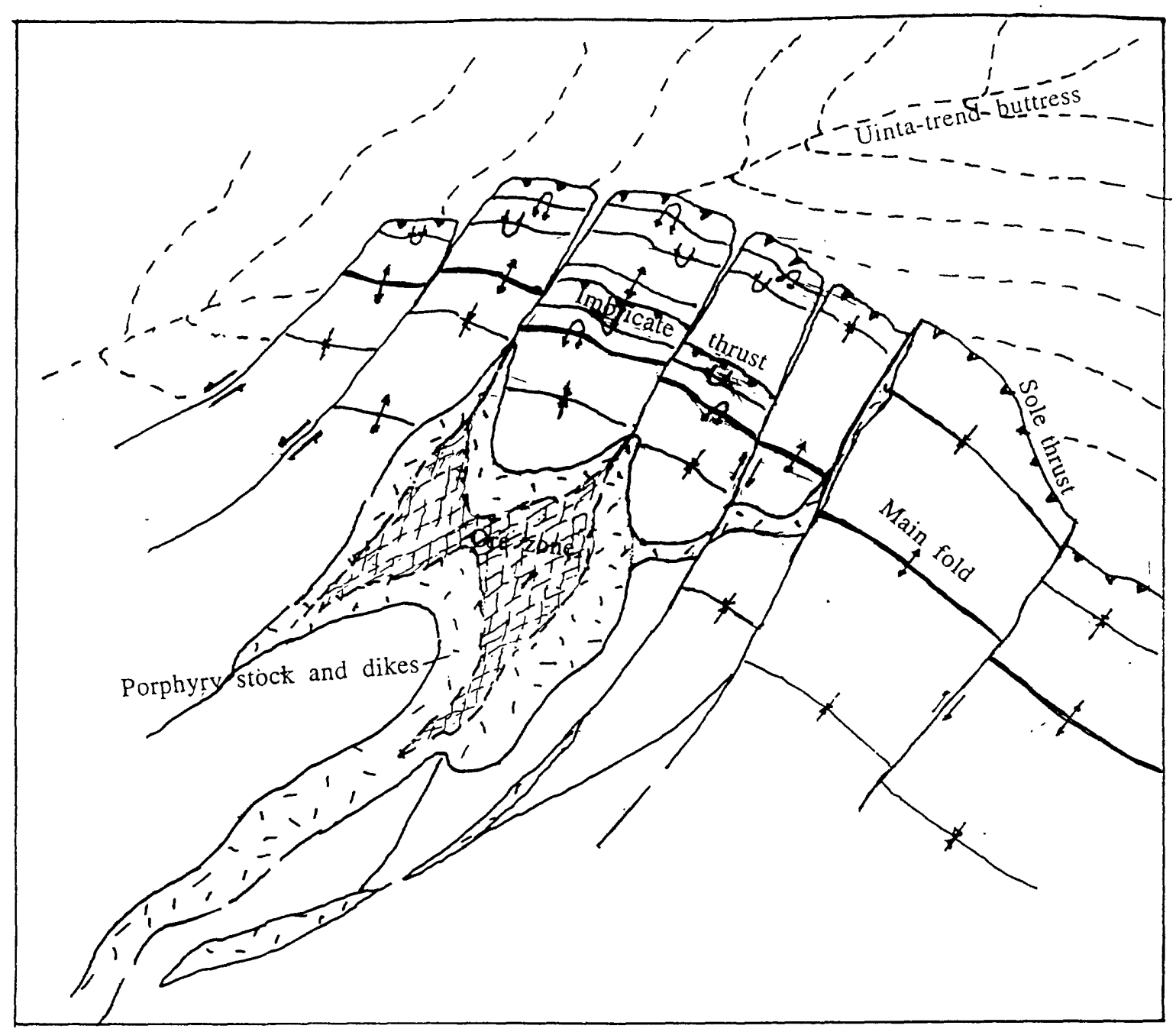




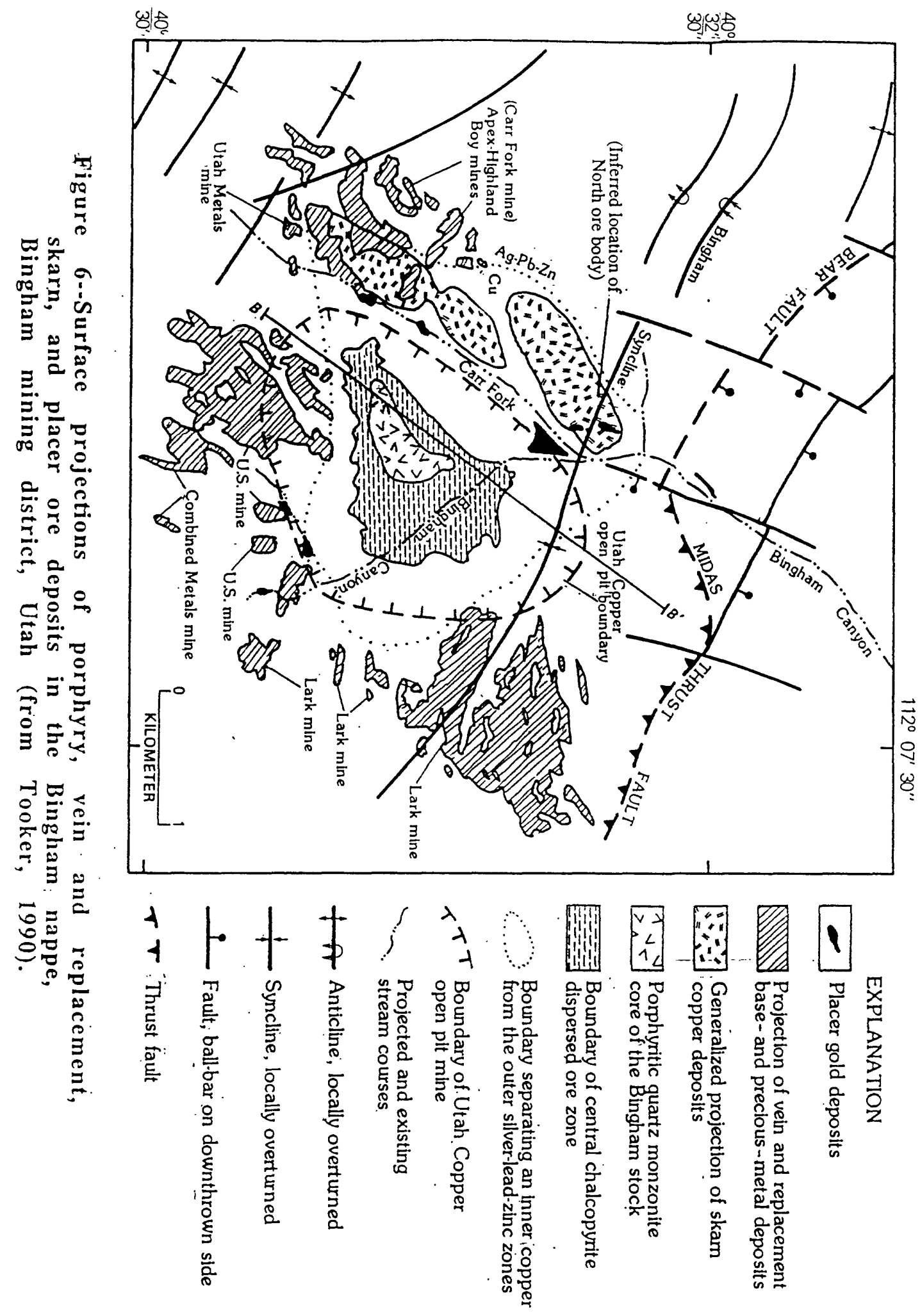


South Mountain

napo

\begin{tabular}{|l}
$\overline{\bar{c}}$ \\
$\overline{3}$ \\
$\frac{5}{3}$ \\
0 \\
0
\end{tabular}

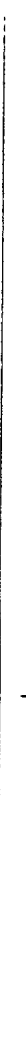

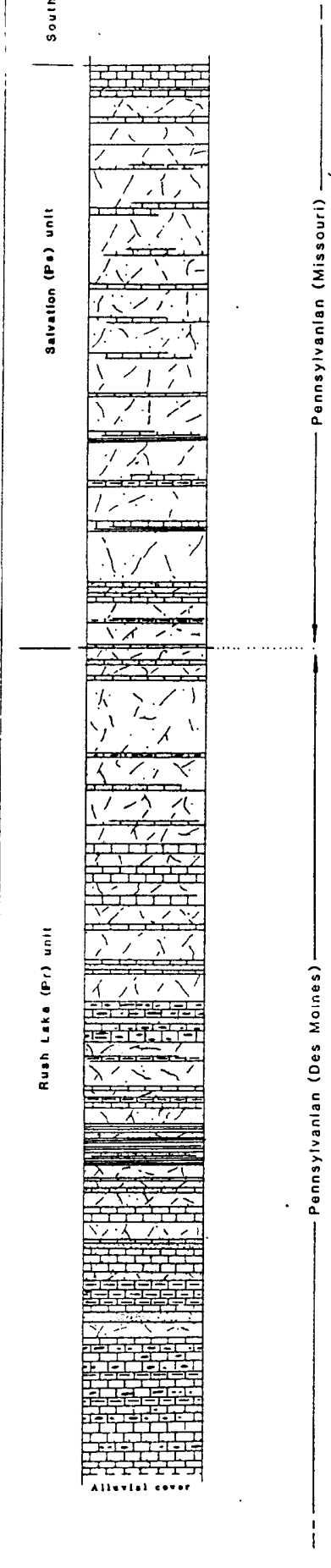

Bingham nappe

to........ R.......1970\}

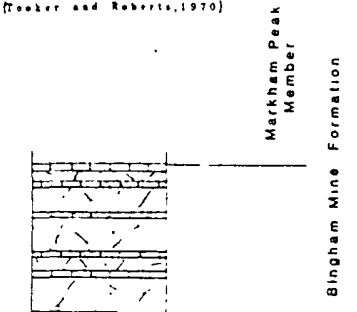

EXPLANATION

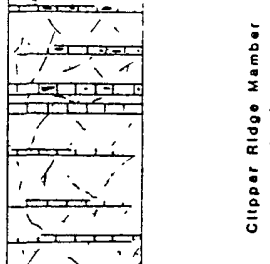

$y<$

1

$\frac{1}{1 !}$

$+$

1,

r

.

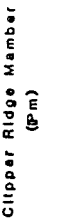

s.t.:.:..

[i, oun......

$\square$ sonasion.

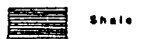

포돔 unotone.

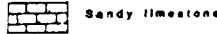

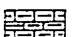

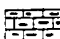

velleat eeste
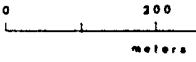
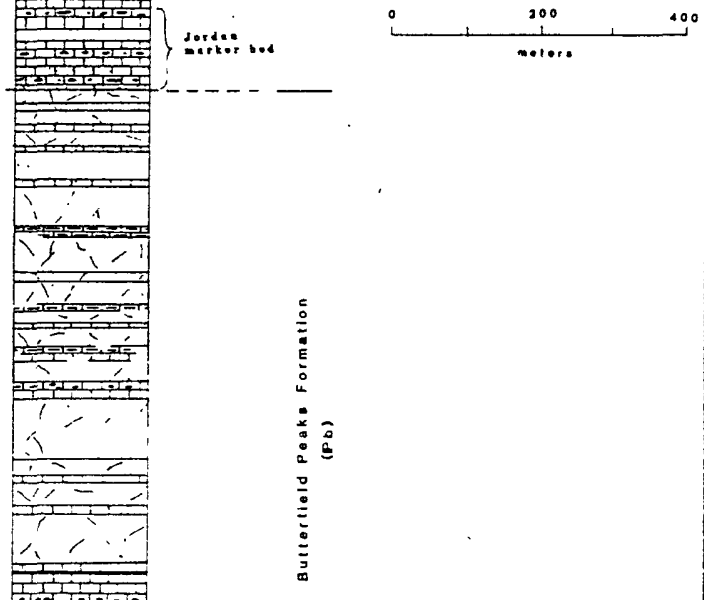

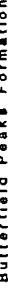
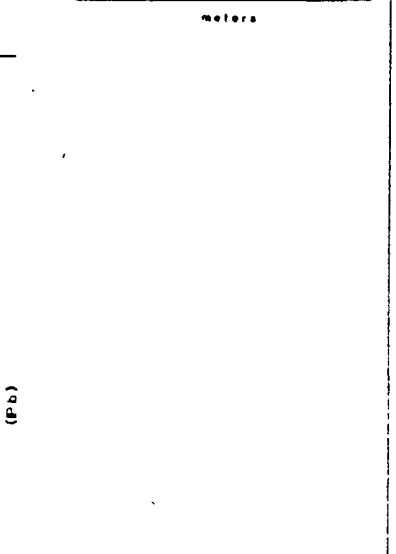

Figure 7 -Columnar stratigraphic sections of comparable parts of the South Mountain nappe in the Stockton 7-1/2-minute quadrangle (Tooker and Roberts, 1992) and Bingham nappe in the Bingham Canyon quadrangle (Tooker and Roberts, 1970, 1988). 


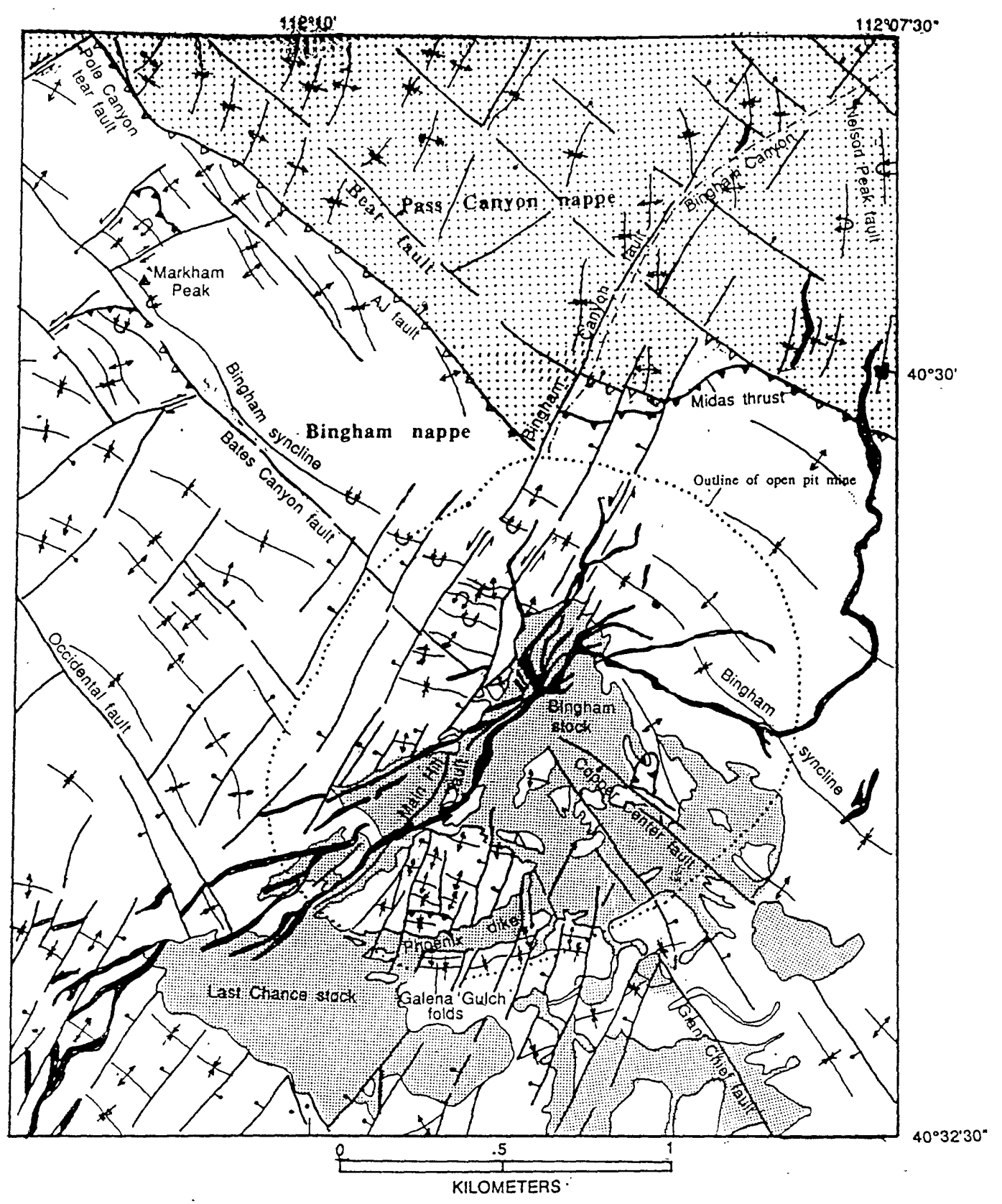

Figure 8--Principal fold and fault structures of the Bingham nappe in the Bingham mining district, Utah (from Tooker and Roberts, 1988).

Tertiary stocks, shaded, and Tertiary dikes solid. Pass Canyon nappe (stippled) includes the Dry Fork unit of Tooker and Roberts (1988). Bingham nappe includes the undivided Markham Peak and Clipper Ridge Members of the Bingham Mine Formation, and the Butterfield Peaks Formation (Troker and Roberts, 1970). Open thrust symbols indicates the thrust is concealed by a normal fault. 


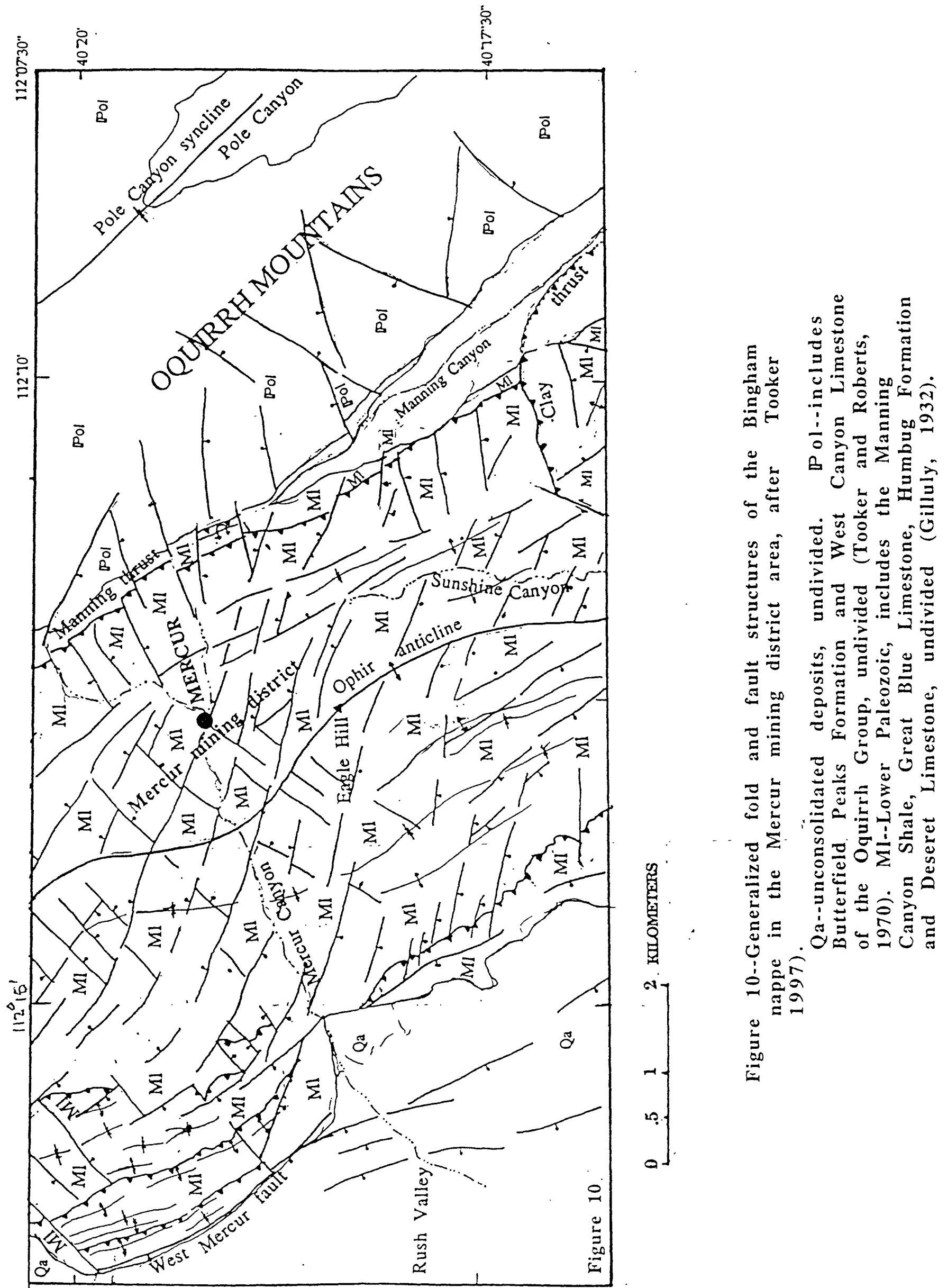




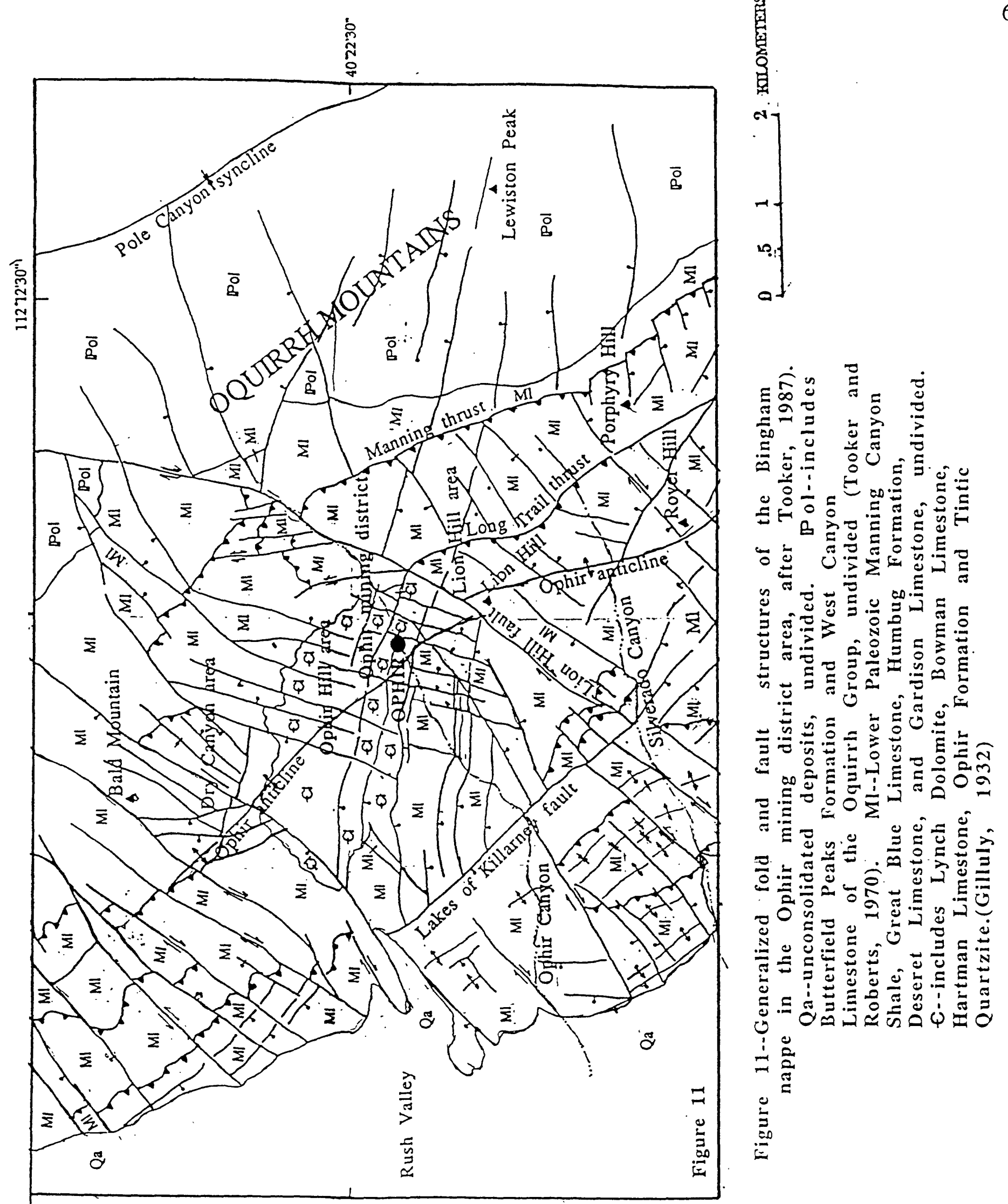




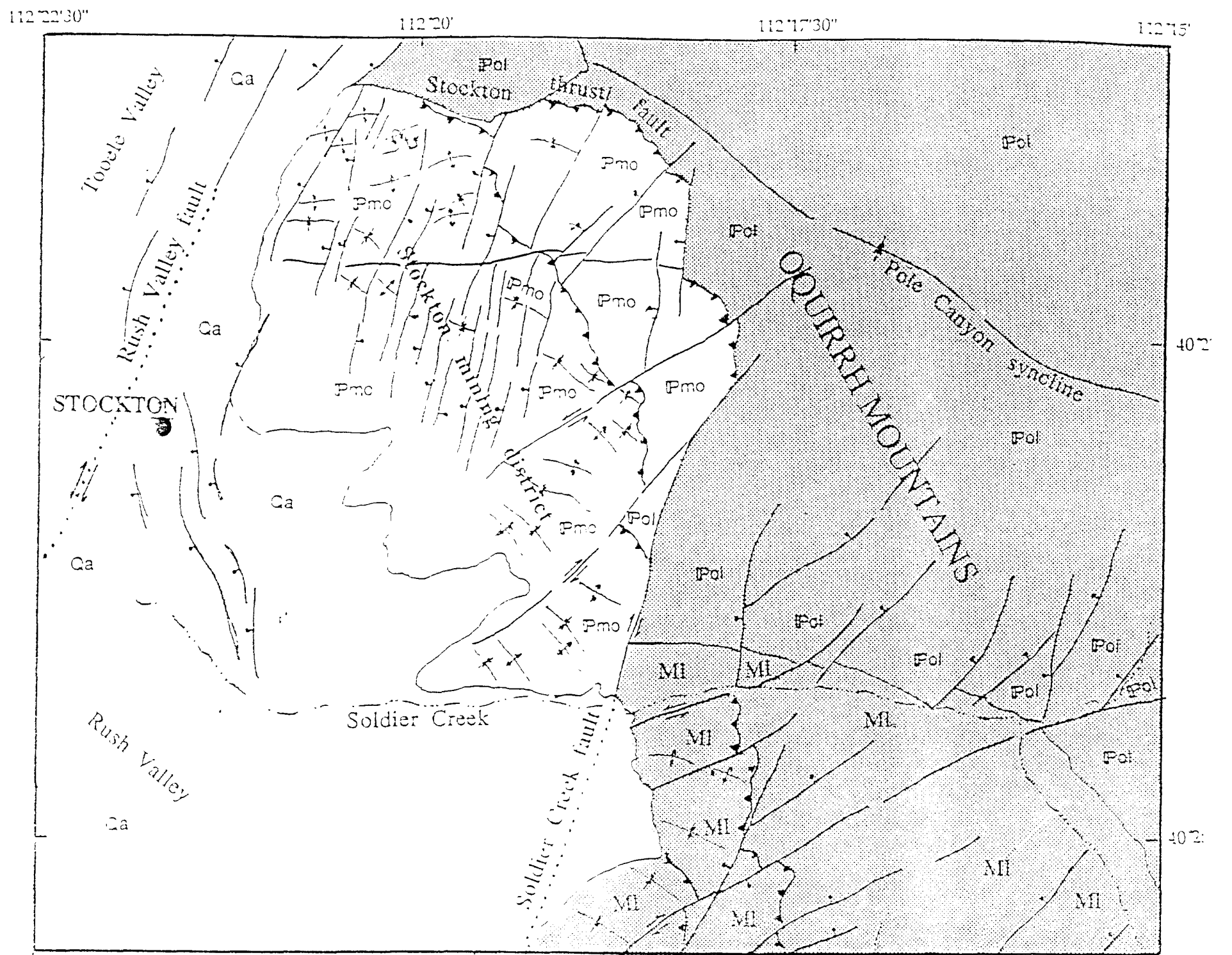

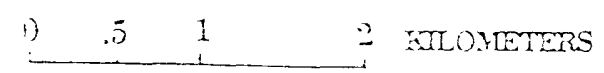

Figure 12.-Generalized fold and fault structures in the eastern half of the South Mountain nappe. the Stockton mining district area and the adjoining Bingham nappe (ate- Tooker and Roberts, 1997)

Qa--Lnconsolidated deposits, undivided. Pmo--Includes Rusin Lake and Salvation units of Tooker and Roberts (1992). undivided. Formations of Tooker and Roberts (1970) in the adjoining Bingham nappe ishaded: include Pol--Butterfield Peaks Formation and West Canyon Limestone of the Oquirrh Group, undivided. MIl includes Manning Canyon Shale, and Great Blue Limestone, undivided. 


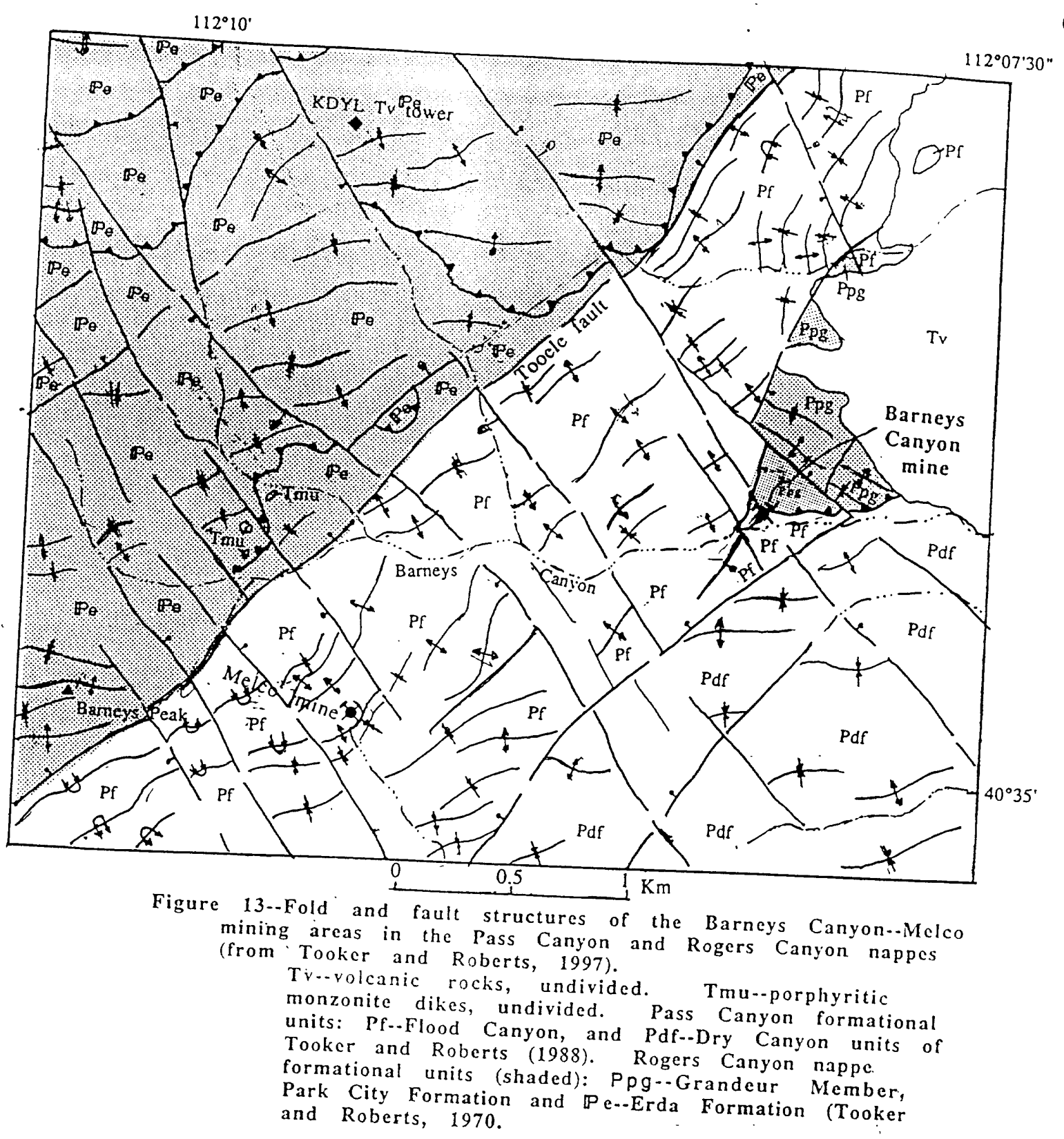


TABLE 1.--Characteristics identifying features of Oquirrh Mountains nappes

$\begin{array}{lll}\text { NAPPES } & \text { SEQUENCE OF DIRECTION OF ENTRY AGES OF FORMATION }\end{array}$
EMPLACEMENT TO FORELAND

\begin{tabular}{|c|c|c|c|}
\hline Pass Canyon & First & $\begin{array}{l}\text { East-northeast to east- } \\
\text { southeast }\end{array}$ & $\begin{array}{l}\text { Permian } \\
\text { (Tooker, 1998) }\end{array}$ \\
\hline Bingham & Second & $\begin{array}{l}\text { Mostly due east in } \\
\text { southern part; east- } \\
\text { northeast across the } \\
\text { buttress at north end }\end{array}$ & $\begin{array}{l}\text { Cambrian through } \\
\text { Pennsylvanian (Gilluly, } \\
\text { 1932; and Tooker and } \\
\text { Roberts, 1970) }\end{array}$ \\
\hline Rogers Canyon & Third & South-southeast & $\begin{array}{l}\text { Mississippian through } \\
\text { Permian (Tooker and } \\
\text { Roberts, 1970) }\end{array}$ \\
\hline South Mountain & Fourth (?) & Northeast & $\begin{array}{l}\text { Pennsylvanian and } \\
\text { Permian (Tooker and } \\
\text { Roberts, 1992) }\end{array}$ \\
\hline Fivemile Pass & Last one & North-northeast & $\begin{array}{l}\text { Mississippian } \\
\text { (Tooker, 1998) }\end{array}$ \\
\hline
\end{tabular}


TABLE 2. METAL PRODUCTION FROM THE OQUIRRH MOUNTAINS MINING DISTRICTS, UTAH

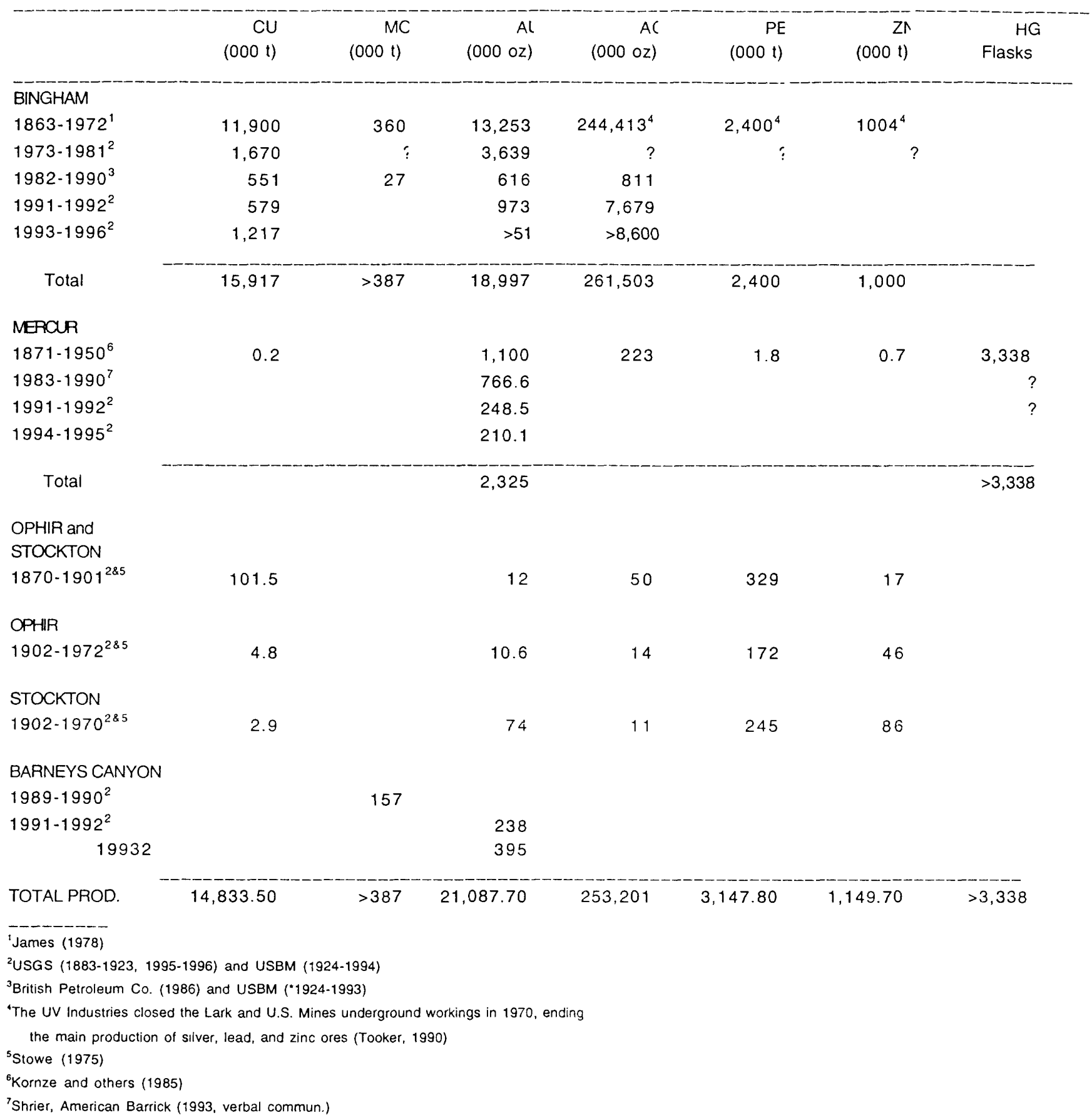


Table 3. Geologic ages of intrusive rocks in mining district areas in the Oquirrh Mountains, Utah

\section{Bingham mining district}

Shaggy Peak rhyolite

Quartz latite porphyry

Porphry copper mineralization

Quartz monzonite porphyry

Monzonite (Last Chance and

Bingham stocks)
35.0-32.8 my

$38.8 \pm 0.3$ (avr)

$39.8-38.8$

38.8

$40.8 \pm 0.4$

Mercur mining district

Rhyolite and rhyolite porphyry (Eagle Hill rhyolite)

Granodiorite porphyry

Quartz monzonite porphyry

Monzonite porphyry
$32.4 \pm 0.9$

$36.7 \pm 0.5$

Stockton mining district

38.1

$38.0 \pm 1.1 \mathrm{my}$
Warnaars and others $(1978$ do

do

Moore (1973b)

Moore (1973c)

Moore and McKee (1983)

Moore (1973c)

Moore and McKee.(1983)

Moore (1973b, 1973c) dates recalculated using updated decay constant. Other dates as reported. 